\title{
Facies, palaeogeography and stratigraphy of the lower Miocene Traisen Formation and Wildendürnbach Formation (former "Oncophora Beds") in the Molasse Zone of Lower Austria
}

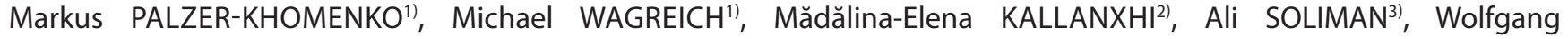 \\ KNIERZINGER ${ }^{1)}$, Maria MESZAR ${ }^{1)}$ \& Susanne GIER ${ }^{1)}$ \\ 1) Department of Geodynamics and Sedimentology, University of Vienna, Althanstraße 14, 1090 Wien, Austria; \\ 2) Department of Geology. Faculty of Biology and Geology, Babeş-Bolyai University, Str. Mihail Kogălniceanu 1, Cluj-Napoca 400084, Romania; \\ 3) Geology Department, Faculty of Science, Tanta University, Tanta 31527, Egypt; \\ ") Corresponding author: markus.palzer@gmx.at
}

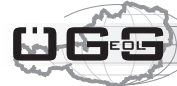

\begin{abstract}
A detailed study of OMV wells throughout the Lower Austrian Molasse Basin demonstrates the existence of a distinct and synchronous upper Ottnangian (lower Miocene) stratigraphic signal, the Calcite Minimum Interval (CMI). It corresponds to the depositional phase of the Rzehakia Lake System. This signal is interpreted to be of chronostratigraphic importance as an expression of palaeoclimate and related sea-level change. It is represented by the brackish Traisen Formation, which crops out south of the Danube. The Traisen Formation correlates with sands and shales in OMV wells to the north, termed Wildendürnbach Formation. However, the CMI underlies a marine unit, the so-called "Oncophora Beds" (also known as Rzehakia Beds) as reported from OMV wells in the north at the border to the Czech Republic. We demonstrate that these former "Oncophora Beds" are younger, i.e. of Karpatian age, than originally assumed. Therefore, these deposits cannot be correlated to the late Ottnangian Traisen Formation. This may solve the problem of contradicting interpretations concerning the depositional environment of both units, which were correlated to each other in the past. As no Rzehakia bivalves (formerly Oncophora) are described from these former "Oncophora Beds", we recommend to avoid using the term for these turbiditic sands. Instead, we attribute these deposits to the fully marine Karpatian Laa Formation. These new findings, which are in accordance with published data from the Czech Republic, indicate two (in time and space) independent sedimentary systems and sand deposition centres for the Traisen Formation and the massive sands attributed as "Oncophora Beds" around Wildendürnbach. A late Ottnangian system in the south delivered the material of the Traisen Formation from the Alps and a Karpatian system delivered the clastic material of the massive sands of the Laa Formation from the east.
\end{abstract}

Detaillierte Untersuchungen an OMV-Bohrungen in der niederösterreichischen Molasse-Zone konnten einen markanten und synchronen stratigrafischen Abschnitt, das Kalzit-Minimum-Intervall (CMI), nachweisen, welches einer lakustrinen Phase, dem „Rzehakia Lake System“, entspricht. Es wird angenommen, dass es sich hierbei um ein synchrones Signal ausgelöst durch Klima- und Meeresspiegelschwankungen handelt. Es schließt die brackische Traisen-Formation, welche südlich der Donau aufgeschlossen ist, mit ein. Die Traisen-Formation korreliert mit Sanden und fein-geschichteten siltigen Tonen der Wildendürnbach Formation, welche weiter nördlich in OMV-Bohrungen angetroffen wurden. Allerdings unterlagert die CMI die marinen sogenannten "Oncophora Schichten" (auch Rzehakia Schichten genannt), welche aus OMV-Bohrungen im Norden an der Grenze zur Tschechischen Republik bekannt sind. Es kann gezeigt werden, dass diese "Oncophora Schichten" dem Karpatium zugeschrieben werden müssen. Demzufolge können die "Traisen-Formation" und die "Oncophora Schichten" einander zeitlich nicht entsprechen, wodurch das Problem widersprüchlicher fazieller Interpretationen dieser Ablagerungen gelöst werden kann. Da innerhalb der "Oncophora Schichten" keine namensgebenden Mollusken der Gattung Rzehakia (früher Oncophora) beschrieben sind, sollte diese Bezeichnung vermieden werden. Stattdessen sollten diese Ablagerungen der marinen, karpatischen Laa-Formation zugerechnet werden. Diese Erkenntnis sowie publizierte Daten aus dem tschechischen Teil des Molasse Beckens lassen darüber hinaus auf 2 unterschiedliche Einspeisungszentren für klastisches Material schließen. Ein Einspeisungszentrum im Süden des Molasse-Beckens liefert während des späten Ottnangiums das klastische Material der Traisen-Formation aus den Alpen. Ein zweites Einspeisungszentrum im Osten liefert im Karpatium die mächtigen Sande der Laa-Formation.

\section{Introduction}

Strata of the Cenozoic Austrian Molasse Basin, a part of the Northern Alpine Foreland Basin system (e.g. Wagner, 1998; Sikula and Nehyba, 2004; Heckeberg et al., 2010) form a thick sedimentary succession in front of the Alpine Orogen, including classical geosites such as the type locality for the Ottnangian regional Paratethys stage of the Early Miocene (e.g. Steininger et al., 1983; Roegl et al., 1997; Wessely, 2006; Grunert et al., 2010a; Heckeberg et al., 2010; Gebhardt et al., 2013; Pippèrr et al., 2018). In contrast to the wellknown and thoroughly investigated Molasse strata of 
Upper Austria and Bavaria (e.g. Robinson and Zimmer, 1989; Kowalke and Reichenbacher, 2005; Rupp et al., 2008; Heckeberg et al., 2010; Pippèrr and Reichenbacher, 2010; Grunert et al., 2012; Grunert et al., 2013; Liebl et al., 2013; Reichenbacher et al., 2013; Sant et al., 2017; Pippèrr et al., 2018), the easternmost Lower Austrian Molasse stratigraphy and facies are still partly underexplored (Wagner, 1998; Roetzel et al., 1999; Krenmayr et al., 2002; Piller et al., 2004; Roetzel et al., 2006; Gebhardt et al., 2013; Wimmer-Frey et al., 2013; Egger et al., 2017; Palzer-Khomenko et al., 2018). For instance, the depositional environment of the lower Miocene, upper Ottnangian (Piller et al., 2004; Piller et al., 2007) Traisen Formation (Gebhardt et al., 2013), predominantly massive mica-rich sands between St. Pölten and Tulln, has been a matter of debate over the past two decades. These deposits were seen as part of the Oncophora or Rzehakia Beds, named after the bivalve Rzehakia (Rzehak, 1882; Čtyroký, 1972; Mandic and Ćorić, 2007). It was assumed that these sands were deposited under brackish conditions in temporally isolated basins of the Paratethys during the prominent Burdigalian Bur4 sea-level lowstand (Čtyroký, 1972; Mandic and Ćorić, 2007; Piller et al., 2007; Gebhardt et al., 2013). Harzhauser and Mandic (2008) interpreted these deposits as part of an Early Miocene Rzehakia Lake System. During that time, the Central Paratethys Sea disintegrated into several basins with extensive brackish water lakes.

Hamilton (1997) described what he thought equivalent to the "Oncophora Beds" in petroleum industry (OMV) wells from Lower Austria as fully marine turbiditic deposits. His interpretation was mainly based on samples of OMV drill cores from wells around Wildendürnbach (Austrian/Czech border), situated $50 \mathrm{~km}$ north of the outcrops of the Traisen Formation. These sediments were deposited at about $1000 \mathrm{~m}$ depth with a thickness of several hundreds of metres and are dominated by deep-water turbiditic and massive sands, as described by Hamilton (1997), Palzer-Khomenko et al. (2018) and internal OMV reports (e.g. Sauer and Kuffner, 1997; Kuffner, 2001; both unpublished). These sands characterise a major sand input centre overlying pelitic sediments. According to similar lithofacies sequences, which means lower Miocene pelitic mica-rich sediments overlain by an interval of turbiditic and massive sands, the formerly called "Oncophora Beds" in the north were correlated to the Traisen Formation (former Oncophora/Rzehakia Beds) outcropping south of the Danube. The discrepancy of a brackish Traisen Formation as part of the Rzehakia Lake System correlated to fully marine "Oncophora Beds" has been a matter of debate for years.

Palzer-Khomenko et al. (2018) investigated several wells throughout the Lower Austrian Molasse Basin (LAMB) and demonstrated a major stratigraphic marker interval, the "Calcite Minimum Interval" (CMI). The CMI was interpreted as a significant lithostratigraphic signal of the Rzehakia Lake System affecting upper Ottnangian sediments. It can be identified by various features such as reduced carbonate contents, increased smectite/illite ratios compared to under- and overlying sediments as well as the absence of (detectable amounts of) pyrite and calcareous nannofossils. For the distal, turbiditic deposits of this interval in the central basinal parts of the LAMB, Palzer-Khomenko et al. (2018) introduced and defined the Wildendürnbach Formation. The present study correlates the Traisen Formation with the Wildendürnbach Formation in the well of Wildendürnbach K4 and demonstrates that the (former) "Oncophora Beds" sensu OMV are overlying this interval and therefore correspond to the Karpatian Laa Formation.

\section{Geological setting}

The LAMB is situated between the Bohemian Massif to the NW, the Rhenodanubian Flysch Zone and the Northern Calcareous Alps (NCA) as part of the Alpine orogen to the $S$, the Waschberg Unit to the $E$ and the Carpathian orogen to the NE (Fig. 1). To the N, the LAMB continues into the Czech Carpathian Foreland Basin (Nehyba and Sikula, 2007). The sequence of Oligocene-Miocene sediments up to $2000 \mathrm{~m}$ thickness is dominated by mica-rich sands and pelites transported from the Alps and the Carpathians. Mica-poor and quartz-rich sands derived from the Bohemian Massif are of subordinate importance and mostly belong to the (older) Linz-Melk Formation (Fig. 1B; Roetzel and Kurzweil, 1986; Krenmayr and Roetzel, 2000). The mica-rich sands and pelites of the lower Ottnangian "Robulus Schlier", the upper Ottnangian Traisen Formation and the Karpatian Laa Formation make up the major part of the sedimentary infill of the LAMB (Roegl et al., 1997; Krenmayr et al., 2002; Piller et al., 2004; Wessely, 2006; Gebhardt et al., 2013; Wimmer-Frey et al., 2013; Egger et al., 2017; PalzerKhomenko et al., 2018). Characteristic for these sediments are the garnet-dominated heavy mineral spectra and the fluctuating sand/pelite ratio (Knierzinger et al., 2018). The high frequency, millimetre-to-centimetre intercalations of sands and pelites are termed "Schlier", which is still in use for many (informal) lithostratigraphic terms in the Austrian Molasse (e.g. "Sandstreifenschlier", "Robulus Schlier" and "Haller Schlier"; Piller et al., 2004; Wessely, 2006; Rupp et al., 2008; Wimmer-Frey et al., 2013; Egger et al., 2017).

The Traisen Formation is exposed south of the Danube, at the southern to south-eastern rim of the LAMB between St. Pölten and Tulln. According to the definition of Gebhardt et al. (2013), it comprises both a dominating facies of massive sands and a fine-grained lithofacies of subordinated importance. Both sands and pelites show strongly reduced calcite contents (already noticed in the field by using diluted $5 \%$ hydrochloric acid) compared to the overlying Laa Formation and the underlying Robulus Schlier. The pelites lack calcareous nannofossils. The only exceptions to the overall carbonate paucity are frequently occurring spherical carbonate concretions with a diameter of up to $1 \mathrm{~m}$.

The turbiditic, time-equivalent continuation of the Traisen Formation to the NE is represented by the Wildendürnbach Formation (Palzer-Khomenko et al., 


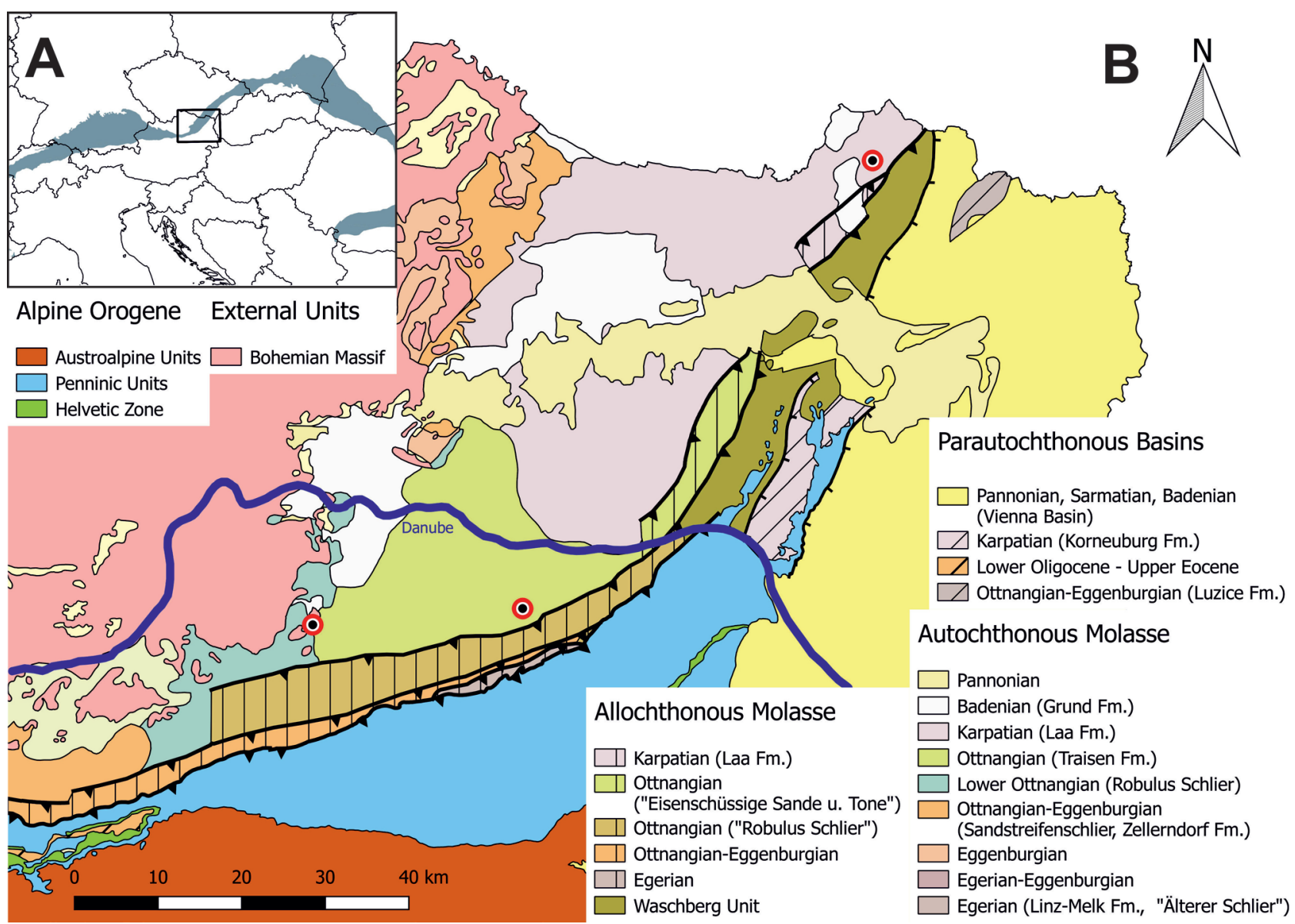

Figure 1. Adapted maps of Palzer-Khomenko et al. (2018). A: Schematic overview of the Alpine-Carpathian foreland basins and the position of the study area. B: Schematic geological map of the study area and investigated wells (map compilation, Wessely, 2006; Schuster et al., 2015).

2018), mostly known from OMV wells. Its lower and upper lithostratigraphic boundaries were defined by the limits of the CMI. The Wildendürnbach Formation consists of non-calcareous, microfossil-free pelites interrupted by coarse clastic slumps, debris flows and some turbidites. The Wildendürnbach Formation, the Traisen Formation and the locally occurring gravelly Dietersdorf Formation form the Pixendorf Group (Gebhardt et al., 2013).

The upper Ottnangian Pixendorf Group overlies the lower Ottnangian "Robulus Schlier". The "Robulus Schlier" consists of mica-rich pelitic sediments with subordinate sand intercalations and contains a calcareous nannofossil assemblage indicating the nannofossil zones NN3-NN4 (Ćorić and Roegl, 2004; Wimmer-Frey et al., 2013; Egger et al., 2017) of Martini (1971).

North of the Danube, the Pixendorf Group is overlain by the Karpatian Laa Formation. The Laa Formation consists of mica-rich sands and pelites with a largely similar composition compared to the Traisen Formation, except for a higher calcite content and the presence of a Karpatian calcareous nannofossil and foraminiferal assemblage (Ćorić and Roegl, 2004; Gebhardt et al., 2013).

Palaeogeographically, a connection between the Central Paratethys and the Mediterranean existed during the early Ottnangian (ca. 18 Ma; Krijgsman and Piller, 2012) via Lower and Upper Austria, Bavaria, Switzerland and France. This connection was closed in the late Ottnangian
(Roegl and Steininger, 1983; Bieg, 2005). The Upper Austrian and Bavarian parts of the Molasse Basin were isolated and separated from the Lower Austrian part by the structural high of the Amstetten Swell at the southern tip of the Bohemian Massif. The palaeogeographic situation and depositional setting in the LAMB is still under debate (Kapounek et al., 1965; Bieg, 2005; Peña, 2007; Kováč et al., 2017; Sant et al., 2017). The model of an isolated brackish basin belonging to the Rzehakia Lake System (Harzhauser and Mandic, 2008) is supported by mollusc assemblages of the Traisen Formation with the occurrence of the brackish to fresh-water bivalve Rzehakia (Mandic and Corić, 2007; Gebhardt et al., 2013). On the other hand, geologists of OMV brought forward the idea of a fully marine late Ottnangian Molasse Basin based on microfossil investigations of well data, which were interpreted as evidence for a prevailing marine connection to the E during the "late" Ottnangian (Hamilton, 1997). In contrast, Czech workers already correlated these units to Karpatian deposits in the Czech Republic (Aniwandter et al., 1990; Sikula and Nehyba, 2004; Nehyba and Sikula, 2007).

\section{Materials and methods}

Throughout this study, a total of 280 drill core samples and additional 164 samples of cuttings of seven wells were analysed. Three wells were chosen for the 
comparison and correlation of the Traisen Formation and the "Oncophora Beds" sensu OMV around Wildendürnbach: Schaubing (water well, data courtesy by Austrian Geological Survey), Streithofen 1 and Wildendürnbach K4 (Fig. 1). While the shallow $(140 \mathrm{~m})$ and marginal well of Schaubing offered a continuous core, the other industrial wells from more basinal and northern parts provide only sparse core material with stratigraphic gaps of $50 \mathrm{~m}$ in between. Hereinafter, we present data of all 171 drill core samples of the wells of Schaubing, Streithofen 1 and Wildendürnbach $\mathrm{K} 4$.

All samples were powdered and analysed by X-ray diffraction (XRD) and X-ray fluorescence (XRF), as well as for their carbonate content. Thirty samples were chosen for thin sections, 44 for chemical analyses, 46 for organic-walled dinoflagellate cysts investigations (for sample preparation method, see Soliman, 2012) and 67 for calcareous nannofossil investigations by using a modified settling slide method (for sample preparation method, see Burnett, 1998). Tests for washing microfossils were done on 14 samples, but all proved barren of any foraminifera or ostracods. The carbonate content was measured by using a carbonate bomb (Mueller and Gastner, 1971). The bulk mineralogy was analysed by XRD on oriented powdered samples using a Panalytical X'Pert PRO (CuK $\alpha$ radiation, $40 \mathrm{kV}$, $40 \mathrm{~mA}$, step size $0.0167,5 \mathrm{~s}$ per step) diffractometer. Semi-quantitative information was extracted by using peak intensities as counts per second (cps) of characteristic peaks with low or without overlapping problems with other (present) minerals. Background values were subtracted from peak heights. Dry powders were analysed using a Bruker AXS TRACER
IV-SD handheld ED-XRF instrument (XRF). The measured peak intensities were used for inferring semi-quantitative trends calibrated to internal quantitative data, for which elements/oxides were determined by inductively coupled plasma-mass spectrometry (ICP-MS) by the Acmelabs (now Bureau Veritas) in Vancouver, British Columbia, Canada.

The data were plotted against depth using carbonate contents (weight\%), XRD peak heights (counts per second) characteristic for calcite (3.03 $\AA$ ) and pyrite $(2.70 \AA)$, as well as the XRF counts per second for Ca. Samples of calcite-cemented sands, gravels and concretions were excluded from the profile as they would produce outliers obscuring the $\mathrm{CMI}$ signal. They are a common feature within the Traisen Formation and typical for the CMI interval (Gebhardt et al., 2013; Palzer-Khomenko et al., 2018).

\section{Results}

\subsection{Well of Schaubing}

The well of Schaubing offers a 144-m-long continuous drill core from the surface to the crystalline basement of the Bohemian Massif at $130 \mathrm{~m}$ depth (Fig. 1). A description of the drill core is also given in Ćorić et al. (2013). The basal granulites are overlain by a conglomerate and monotonous carbonate-rich silty shales. Layers of coarsegrained sands composed of reworked granulites are intercalated up to $112 \mathrm{~m}$. From $112 \mathrm{~m}$ to $72 \mathrm{~m}$ depth, marly, silty shales containing numerous fish scales become frequent. At $72 \mathrm{~m}$, a first clastic input of fine-grained sands occurs, followed by a clay layer with gypsum rose crystals growing on the drill core. The gypsum is most probably of

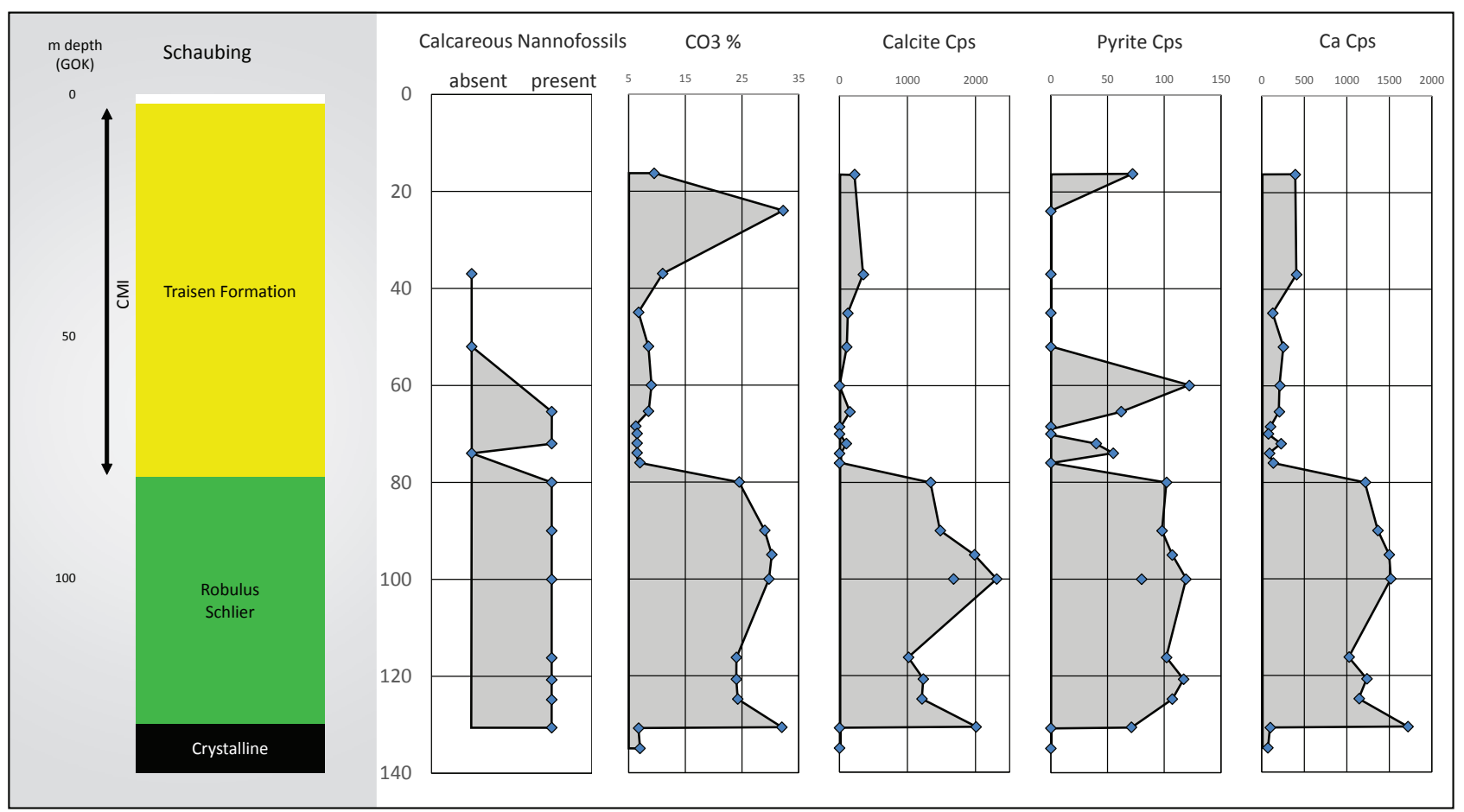

Figure 2. Adapted depth profiles (GOK = depth below surface) of Schaubing of Palzer-Khomenko et al. (2018). Shown are the counted individuals of calcareous nannofossils, weight\% of carbonate and characteristic XRD peak heights (in counts per second) of calcite and pyrite, as well as XRF raw data (counts per second). Please note that the depth scales differ in Figures 2, 4, 5, 6. 
secondary origin due to the decay of pyrite. Above $72 \mathrm{~m}$, calcite is not detectable by the hydrochloric acid test. The proportion of sand increases. Above $40 \mathrm{~m}$, massive sands and carbonate-cemented sandstones occur.

Twelve samples from the Schaubing borehole were investigated for calcareous nannofossils and dinoflagellate cysts. Concerning the calcareous nannofossils, the samples between $37 \mathrm{~m}$ and $74 \mathrm{~m}$ are barren, while the samples belonging to the interval between $80 \mathrm{~m}$ and $130.6 \mathrm{~m}$ contain moderate-to-poorly preserved specimens (Fig. 2). The most abundant species and taxonomical groups are Coccolithus pelagicus, Reticulofenestra spp., Helicosphaera spp. and reworked nannofossils (for detailed results, see Palzer-Khomenko et al., 2018). Dinoflagellate cysts (Fig. 3) did not occur above $52 \mathrm{~m}$, and only few taxa were found

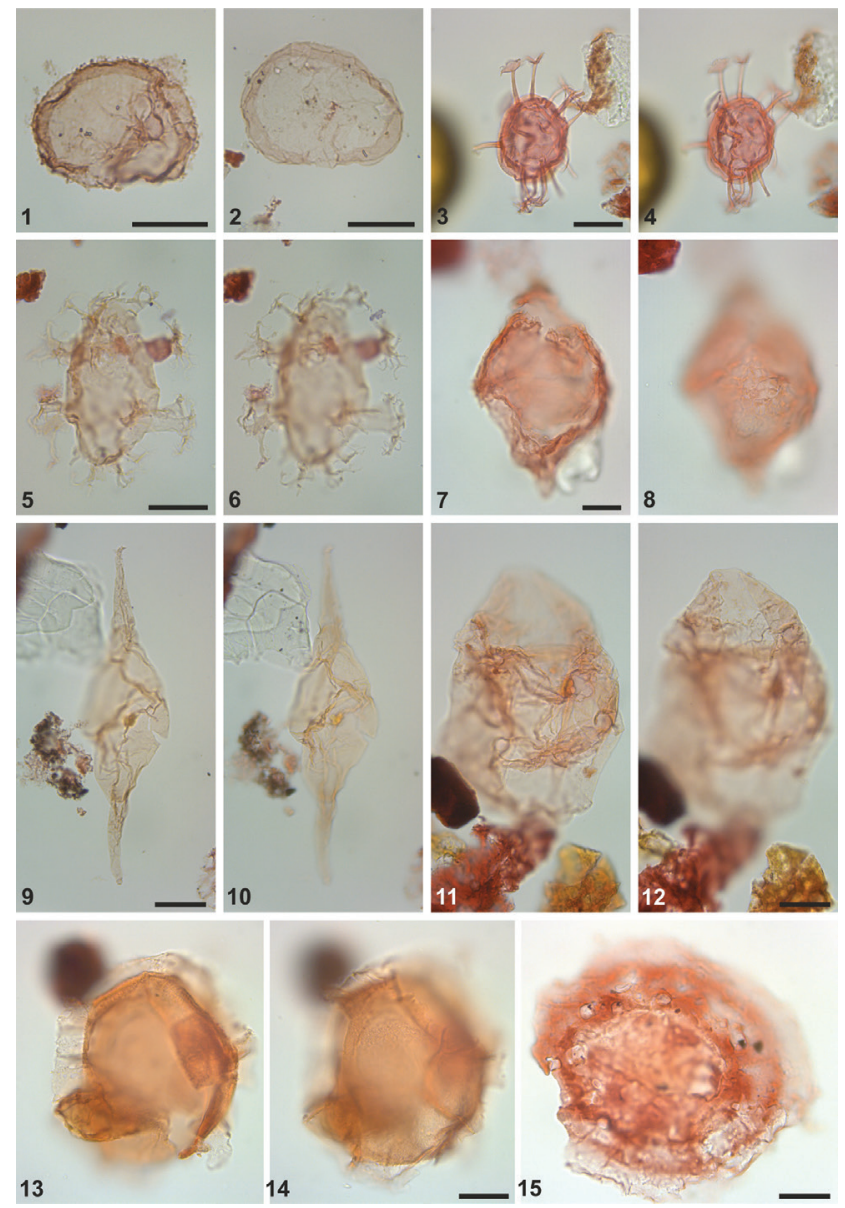

Figure 3. Photomicrographs of dinoflagellate cysts (bright field). Scale bar is $20 \mathrm{~nm}$ for all figures. 1. Selenopemphix brevispinosa Head et al., 1989; Sample WDK4-854.2, Slide1, England Finder E50. 2. Selenopemphix nephroides Benedek emend. Bujak et al., 1980; Samples WDK4-725, Slide 1, England Finder G40-3. 3-4. Melitasphaeridium choanophorum (Deflandre and Cookson) Harland and Hill, 1979; Sample WDK4-854.2, Slide 1, England Finder P50-2. 5-6. Distatodinium paradoxum (Brosius) Eaton, 1976; Sample WDK4-854.2, Slide 1, England Finder S55. 7-8. Apteodinium spiridoides Benedek, 1972; Sample WDK4-1254.2, Slide 1, England Finder A-L44. 9-10. Palaeocystodinium powellii Strauss et al., 2001; Sample WDK4-854.2, Slide 1, England Finder E50-1. 11-12. Hystrichosphaeropsis obscura Habib, 1972; Sample WDK4-1254.2, Slide 1, England Finder T60-3. 13-14. Pentadinium laticinctum Gerlach, 1961 emend. Benedek et al., 1982; Sample WDK4-1254.2, Slide 1, England Finder P58-4. 15. Tuberculodinium vancampoae (Rossignol) Wall, 1967; Sample WDK4-854.2, Slide 1, England Finder E50-4. between $76 \mathrm{~m}$ and $65.4 \mathrm{~m}$. Most dinoflagellate cysts occurred below $80 \mathrm{~m}$. Achomosphaera/Spiniferites spp., Cleistosphaeridium placacanthum/ancyreum complex, Operculodinium centrocarpum, Polysphaeridium zoharyi, Reticulatosphaera actinocoronata and Lingulodinium machaerophorum were most abundant (Table 1A). Prasinophytes spp. were abundantly recorded between $80 \mathrm{~m}$ and $100 \mathrm{~m}$.

The carbonate contents (Fig. 2) are higher than 20\% for all samples below $80 \mathrm{~m}$ depth (except samples of the basement). At $80 \mathrm{~m}$, the carbonate content decreases to $<10 \%$ in all samples, except in a calcite-cemented sand sample at $24 \mathrm{~m}$. This correlates consequentially with a drop in the calcite XRD peak heights and Ca XRF counts. The XRD peak heights of pyrite are $>40 \mathrm{cps}$ at depths below $80 \mathrm{~m}$ and decrease to $<40 \mathrm{cps}$ between $80 \mathrm{~m}$ and $60 \mathrm{~m}$, where strong fluctuations were detected. Except one outlier, pyrite was not detected above $60 \mathrm{~m}$ depth.

\subsection{Well of Streithofen 1}

The well of Streithofen 1 (Fig. 4) is situated in the outcrop area of the Traisen Formation in the southern part of the LAMB (Fig. 1) and provides well-preserved drill cores of $5 \mathrm{~m}$ every $50-150 \mathrm{~m}$. The crystalline basement at $1230 \mathrm{~m}$ is overlain by fluviatile quartz-rich sand/sandstones and coaly clay/mudstones to siltstones. The coaly beds are tectonically fractured and show pieces of polished slickensides. The facies changes from fluviatile to marine with typical strongly bioturbated bluish sandstones between $1140 \mathrm{~m}$ and $1121 \mathrm{~m}$. At $1100 \mathrm{~m}$ follows the pelitic "Schlier" succession of millimetre-to centimetre interbedded silty to clayey shales, yellowish to brownish sands and silts as well as light grey sandstones (Robulus Schlier). Above this, the facies changes to sand-dominated deposits between $850 \mathrm{~m}$ and $800 \mathrm{~m}$. A prominent decrease in carbonate content can be recognised. The sediments above $800 \mathrm{~m}$ comprise the typical Traisen Formation characterised by low carbonate and high mica contents. The Traisen Formation is continuous up to the surface.

Twenty-nine samples from the Streithofen 1 borehole were investigated for calcareous nannofossils. All samples below $1120 \mathrm{~m}$ and above $850 \mathrm{~m}$ are barren, except for a few individuals of Sphenolithus sp. at $654.8 \mathrm{~m}$ and reworked Sphenolithus ciperoensis at $151.5 \mathrm{~m}$ (Fig. 4). The interval between $1120 \mathrm{~m}$ and $850 \mathrm{~m}$ contains only very few calcareous nannofossils. The most abundant species is Coccolithus pelagicus, followed by scarce Reticulofenestra hagii, Sphenolithus moriformis, Cyclicargolithus floridanus and $R$. pseudoumbilicus (for detailed results, see Palzer-Khomenko et al., 2018). Seventeen samples were investigated for dinoflagellate cysts. All samples between $250 \mathrm{~m}$ and $990 \mathrm{~m}$ are barren. Few individuals of Cribroperidinium sp. and undetermined cysts are found in three samples above $250 \mathrm{~m}$. Rare and poorly preserved dinoflagellate cysts occur below 990 m. Glaphyrocysta spp., Cleistosphaeridium spp., Cordosphaeridium cantharellus, Spiniferites/Achomosphaera spp. and Lingulodinium machaerophorum are the most abundant species (Tab. 1B). 


\begin{tabular}{|c|c|c|c|c|c|c|c|c|c|c|c|c|c|}
\hline \multicolumn{10}{|c|}{ Lower Miocene } & \multirow{2}{*}{\multicolumn{2}{|c|}{ : }} & \multirow{2}{*}{\multicolumn{2}{|c|}{ Age }} \\
\hline \multicolumn{7}{|c|}{ Ottnangian } & \multicolumn{3}{|c|}{ ? Ottnangian } & & & & \\
\hline $\begin{array}{l}\tilde{0} \\
\hat{0} \\
\dot{\hat{n}} \\
\hat{\tilde{\sigma}} \\
\vec{\omega} \\
\dot{0} \\
\sigma\end{array}$ & $\begin{array}{l}\tilde{O} \\
\vec{a} \\
\dot{u} \\
\hat{\tilde{O}} \\
\overrightarrow{\tilde{\sigma}} \\
\overrightarrow{+} \\
\dot{\infty}\end{array}$ & 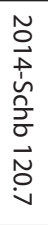 & 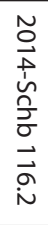 & 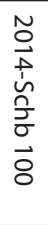 & 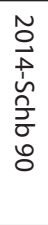 & 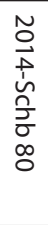 & 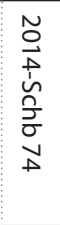 & 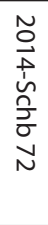 & 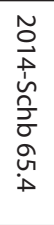 & 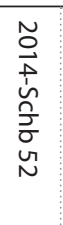 & 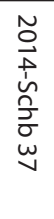 & \multicolumn{2}{|l|}{ Samples } \\
\hline$\ddot{v}$ & ๑ & u & $\stackrel{\infty}{\omega}$ & $\widetilde{\circ}$ & $\stackrel{\circ}{\not}$ & $\not{D}$ & & $\omega$ & $\rightarrow$ & & & Achomosphaera/Spiniferites spp. & \multirow{28}{*}{ 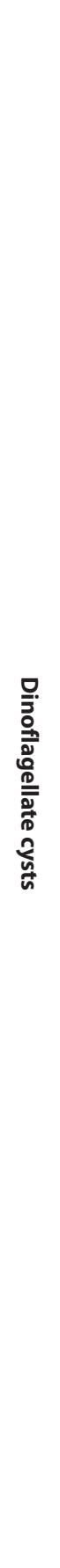 } \\
\hline$\sim$ & $\triangle$ & - & - & $N$ & $\vec{\infty}$ & $u$ & & - & - & & & Polysphaeridium zoharyi & \\
\hline N & $\sim$ & $\tilde{\omega}$ & $\vec{\bullet}$ & - & v & v & & - & - & & & Lingulodinium machaerophorum & \\
\hline 9 & $\approx$ & $\vec{\perp}$ & ज̆ & 6 & w & $\stackrel{\infty}{\infty}$ & & - & - & & & C. placacanthum/ancyreum complex & \\
\hline \multirow[t]{2}{*}{$a$} & $v$ & $\rightarrow$ & v & $\rightarrow$ & $\vec{N}$ & 6 & & $a$ & - & & & Apteodinium spiridoides & \\
\hline & - & & & - & & & & - & $\omega$ & & & Batiacasphaera sphaerica & \\
\hline$v$ & 6 & $\sim$ & v & N & $a$ & $\infty$ & & & $\sim$ & & & Distatodinium paradoxum & \\
\hline$\vec{\infty}$ & $\vec{o}$ & $v$ & $\vec{\perp}$ & $\rightarrow$ & $\sim$ & 0 & & & & & & Operculodinium centrocarpum & \\
\hline- & - & & & & $\sim$ & $\sim$ & & & & & & Hystrichokolpoma denticulatum & \\
\hline$\sim$ & $\sim$ & - & $\vec{N}$ & - & - & $\approx$ & & & & & & Reticulatosphaera actinocoronata & \\
\hline$v$ & $a$ & $\rightarrow$ & - & $a$ & $\omega$ & + & & & & & & Lejeunecysta spp. & \\
\hline$\omega$ & $a$ & & - & $\sim$ & $\sim$ & $\rightarrow$ & & & & & & Hystrichokolpoma rigaudiae & \\
\hline- & $\sim$ & & - & $\omega$ & - & $\omega$ & & & & & & Pentadinium laticinctum & \\
\hline- & v & - & & & - & - & & & & & & Cribroperidinium giuseppei & \\
\hline \multirow[t]{5}{*}{-} & - & $\sim$ & & & v & - & & & & & & Dapsilidinium pastielsii & \\
\hline & - & & & - & - & - & & & & & & Tuberculodinium vancampoae & \\
\hline & & & & & n & $\omega$ & & & & & & Cousteaudinium aubryae & \\
\hline & & & & & $\sim$ & - & & & & & & Palaeocystodinium powellii & \\
\hline & & & & & & - & & & & & & Selenopemphix brevispinosa & \\
\hline \multirow[t]{4}{*}{$\rightarrow$} & - & - & $\omega$ & $\approx$ & $\sim$ & & & & & & & Round brown cysts & \\
\hline & & & & & $\sim$ & & & & & & & Caligodinium pychnum & \\
\hline & - & & & $\omega$ & & & & & & & & Selenopemphix nephroides & \\
\hline & & & & $\sim$ & & & & & & & & Selenopemphix brevispinosa & \\
\hline \multirow[t]{2}{*}{-} & $\sim$ & & & - & & & & & & & & Melitasphaeridium choanophorum & \\
\hline & - & & & & & & & & & & & Hystrichosphaeropsis obscura & \\
\hline \multirow[t]{2}{*}{ n } & v & & & & & & & & & & & Homotryblium tenuispinosum & \\
\hline & - & & & & $a$ & $\rightarrow$ & & & & & & indet. cysts & \\
\hline \multirow[t]{4}{*}{$\overrightarrow{0}$} & $\tilde{D}$ & $\overrightarrow{\vec{\omega}}$ & $\tilde{8}$ & 穴 & $\tilde{\Xi}$ & 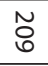 & & $\vec{\omega}$ & $=$ & & & Total dinocysts count & \\
\hline & - & N & v & & & & & & & & & Tasmanites spp. & \multirow{3}{*}{ 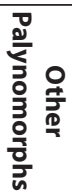 } \\
\hline & - & & & & & & & & & & & Cyclopsiella spp. & \\
\hline & & - & & $\vec{v}$ & $\overrightarrow{0}$ & $\infty$ & & & & & & Paralecaniella spp. & \\
\hline
\end{tabular}




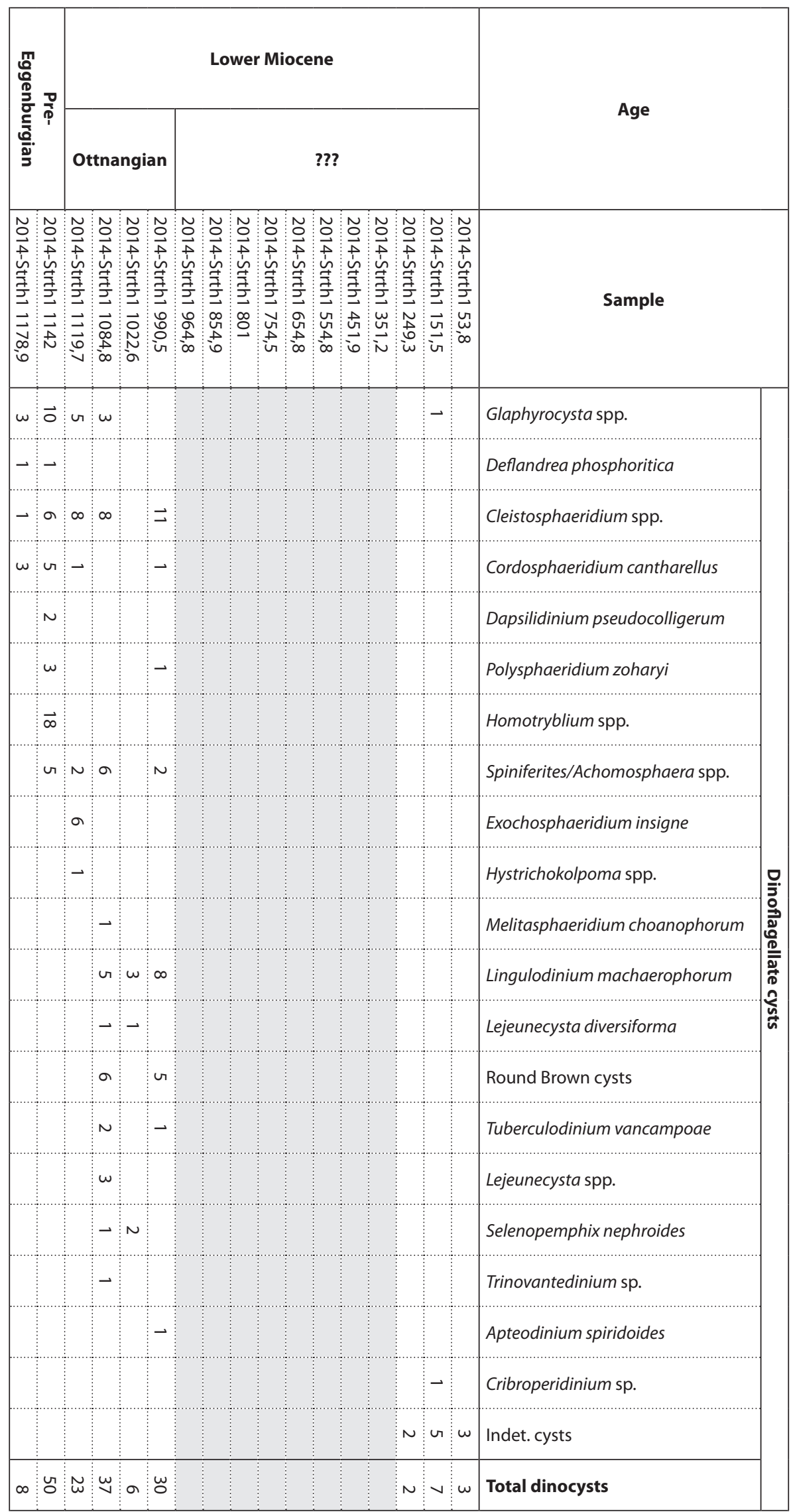




\begin{tabular}{|c|c|c|c|c|c|c|c|c|c|c|c|c|c|c|c|c|}
\hline \multirow{2}{*}{\multicolumn{6}{|c|}{ ?? Lower Miocene }} & \multicolumn{10}{|c|}{ Lower Miocene } & \multirow{2}{*}{ Age } \\
\hline & & & & & & \multicolumn{10}{|c|}{ Ottnangian } & \\
\hline 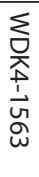 & 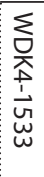 & 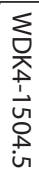 & 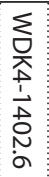 & 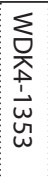 & 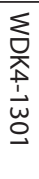 & 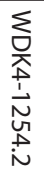 & 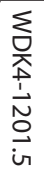 & 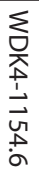 & 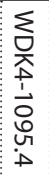 & 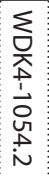 & 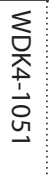 & $\begin{array}{l}\sum_{\infty} \\
\text { त } \\
\dot{+} \\
w \\
\infty \\
\infty\end{array}$ & 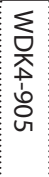 & 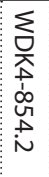 & 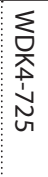 & Sample \\
\hline
\end{tabular}

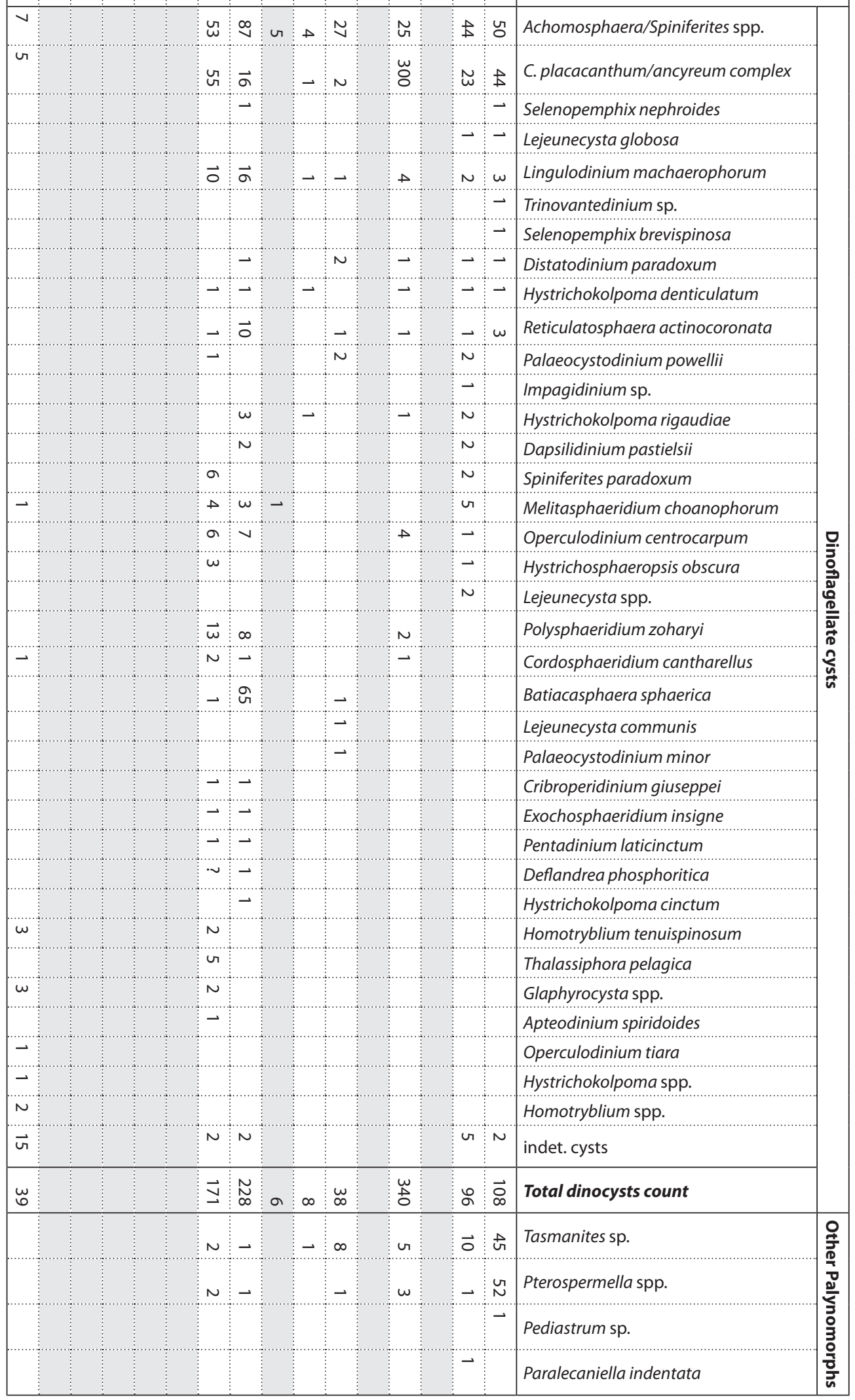




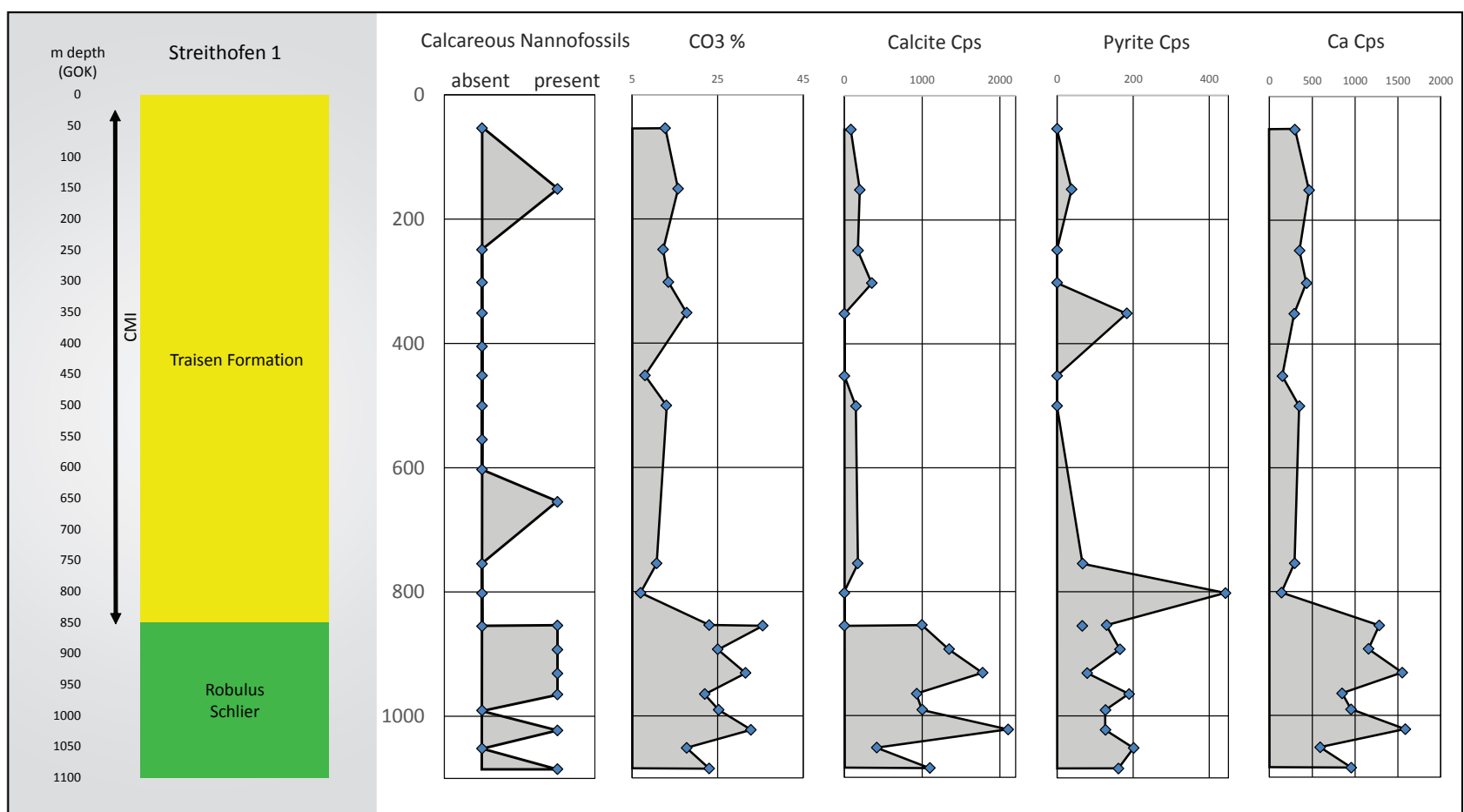

Figure 4. Adapted depth profiles of Streithofen 1 of Palzer-Khomenko et al. (2018). Shown are counted individuals of calcareous nannofossils, weight\% of carbonate and characteristic XRD peak heights (in counts per second) of calcite and pyrite, as well as XRF raw data (counts per second). Please note that the depth scales differ in Figures 2, 4, 5, 6.

The carbonate content varies between $5 \%$ and $70 \%$, whereas most of the samples do not reach values above $40 \%$, except the calcite-cemented outliers (excluded from Fig. 4). The sands overlying the crystalline basement are characterised by carbonate contents mostly $<10 \%$. The bioturbated sandstones at $1120 \mathrm{~m}$ and the overlying pelites and intercalated sand layers up to $890 \mathrm{~m}$ show contents between $15 \%$ and $40 \%$. At 800 m depth, the carbonate content drops below 20\% and ranges between $9 \%$ and $15 \%$. The calcite XRD peak heights (cps) and XRF counts of Ca correlate to the carbonate content. The XRD peak heights of pyrite show a maximum value at $800 \mathrm{~m}$ and a fall at $750 \mathrm{~m}$.

\subsection{Well of Wildendürnbach K4}

The well of Wildendürnbach K4 to the northeast of the study area (Fig. 1) was investigated in detail between $750 \mathrm{~m}$ and $1564 \mathrm{~m}$. According to various internal reports of OMV, notes on Self-Potential Logs (SP-Logs) and the OMV database, the so called "Oncophora Beds" should be present between $1250 \mathrm{~m}$ and $750 \mathrm{~m}$ or between $1000 \mathrm{~m}$ and $800 \mathrm{~m}$. In contrast, Palzer-Khomenko et al. (2018) recently identified and defined a new lithostratigraphical unit, the Wildendürnbach Formation, as the distal, turbiditic coeval equivalent of the proximal Traisen Formation.

Drill cores were available every $50 \mathrm{~m}$. In some cases, $<50 \mathrm{~cm}$ of the original $2-4 \mathrm{~m}$ of core (according to internal OMV archives) were left. The material was unsorted, and it was not possible to reconstruct the orientation in most cases. In some cases, the drill core thickness varied, which indicates that the material was partly mixed up with the drill cores of other wells. Such material as well as drill gouges were excluded from our interpretation. Despite these qualitative drawbacks, the overall characteristics in a larger context could be reconstructed.

The drill cores comprise shales, well-to-poorly sorted brownish-to-yellowish silt/siltstones and light grey sand/ sandstones with different degrees of consolidation. The light grey sands are monotonous, micaceous and mostly rich in carbonate. They contain clay clasts and plant remnants. Fining upward trends, erosional surfaces at the base, planar stratification and ripple structures are common features. The brownish slits show convolute bedding, fining upward trends as well as erosional surfaces and contain a much higher amount of rip-up clasts. The hemipelagic-to-pelagic shales show changing carbonate contents. They are mostly millimetre-laminated and contain shell fragments, fish scales and plant remnants.

The core sections below 1530 m show strongly bioturbated fine-grained and massive sands. Fish scales and plant remnants are common, especially on the bedding planes. Between $1500 \mathrm{~m}$ and $1250 \mathrm{~m}$, bluish grey clayey shales dominate, which are seen as pelitic background sedimentation. They are interrupted by light grey sands and brownish silts. Between $1250 \mathrm{~m}$ and $1150 \mathrm{~m}$, the amount of light grey sands increases. In some OMV internal descriptions, these sands have been previously attributed to the "Oncophora Beds". Between $1150 \mathrm{~m}$ and $1000 \mathrm{~m}$, the amount of light grey sands and brownish silts is strongly reduced. From $1000 \mathrm{~m}$ to $800 \mathrm{~m}$, the sand content dominates and increases upwards. This interval represents the "Oncophora Beds sensu stricto". 
At $750 \mathrm{~m}$, the succession is again dominated by laminated shales. The profile in Figure 5 comprises data of pelitic samples only. They represent the fine-grained background sedimentation. The intercalated turbidites and mudflows tend to obscure the CMI signal.

Twenty-three samples were analysed for the calcareous nannofossil contents. Fifteen samples in general and all except one sample between $1090 \mathrm{~m}$ and $1504 \mathrm{~m}$ are seen to be barren of nannofossils. The remaining samples contain moderate-to-poorly preserved nannofossils, in which the most abundant species and taxonomical groups are as follows: Coccolithus pelagicus, Reticulofenestra spp. and reworked nannofossils. Lower amounts of Helicosphaera spp., Sphenolithus spp. and Braarudosphaera bigelowii are present (for detailed results, see Palzer-Khomenko et al., 2018). Sixteen samples were analysed for dinoflagellate cysts (Table 1C). The interval between $1533 \mathrm{~m}$ and $1301 \mathrm{~m}$ is barren. Above $1255 \mathrm{~m}$, Achomosphaera/Spiniferites spp. and Cleistosphaeridium placacanthum/ancyreum complex are most abundant. Prasinophytes alga, Tasmanites and Pterospermella are recorded sporadically in most samples and are found abundantly at $725 \mathrm{~m}$.

The carbonate contents of the well of Wildendürnbach $\mathrm{K} 4$ range between $<5 \%$ and $30 \%$. The samples at $1560 \mathrm{~m}$ show carbonate contents of $25 \%-30 \%$, followed by a decrease down to $10 \%$. In the following layers, carbonate percentage, calcite XRD counts and Ca XRF counts show large variations within each investigated $5 \mathrm{~m}$ drill core, especially for sands. A more continuous profile can be seen if only pelitic samples are taken into account, which represent the background sedimentation (Fig. 5). This results in the identification of an interval of low calcite values between $1535 \mathrm{~m}$ and $1300 \mathrm{~m}$. After a short interval of elevated calcite contents, a sudden decrease occurs again at $1100 \mathrm{~m}$. Pyrite contents decrease after a prominent peak at $1530 \mathrm{~m}$ and fully recover at $1100 \mathrm{~m}$.

\section{Discussion}

\subsection{Biostratigraphy}

Following the interpretation of Palzer-Khomenko et al. (2018), the calcareous nannofossil biostratigraphy indicates that the entire section of Schaubing, the investigated interval of Wildendürnbach K4 above $1250 \mathrm{~m}$ (as all samples below were barren) and most of the section of Streithofen 1 belong to the interval of NN3 Sphenolithus belemnos Zone (defined at the base by the Last Occurrence [LO] of Triquetrorhabdulus carinatus and at the top by the LO of Sphenolithus belemnos) to NN4 - Helicosphaera ampliaperta Zone (defined by the LO of Sphenolithus belemnos at the base and by the LO of Helicosphaera ampliaperta at the top) of Martini (1971), which corresponds to the late Early Miocene, i.e. Ottnangian and/or Karpatian age (middle/late Burdigalian, Piller et al., 2007). This age assignment is also proven by dinoflagellate cyst data based on the occurrence of Cordosphaeridium cantharellus and Exochosphaeridium insigne (Jiménez-Moreno et al., 2006; Soliman et al., 2012). In

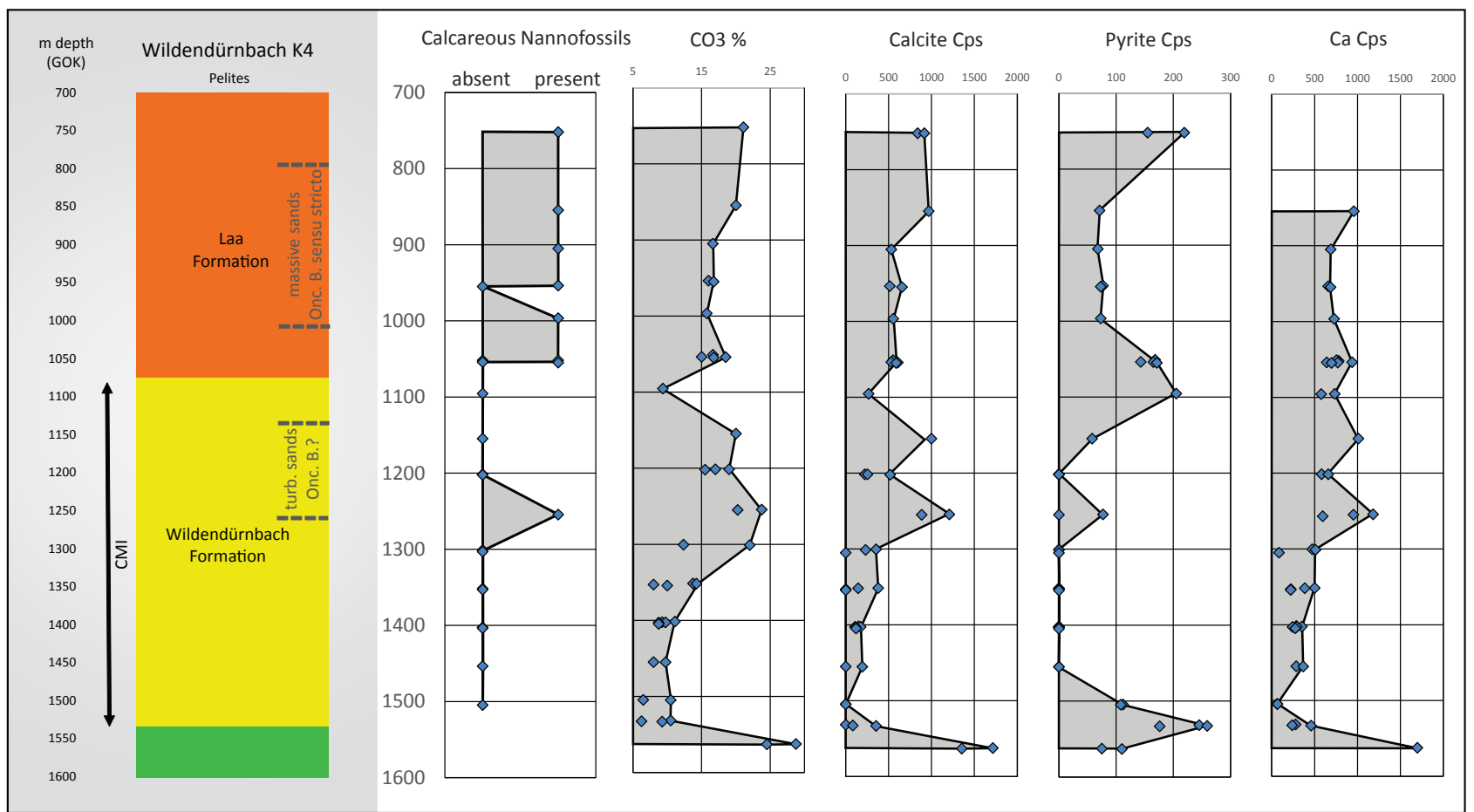

Figure 5. Adapted depth profiles of Wildendürnbach K4 of Palzer-Khomenko et al. (2018). Shown are counted individuals of calcareous nannofossils, weight\% of carbonate and characteristic XRD peak heights (in counts per second) of calcite and pyrite, as well as XRF raw data (counts per second). The extension of the turbiditic sands and massive sands, which were seen as Oncophora Beds in the past (Hamilton, 1997; Sauer and Kuffner, 1997), are indicated by the grey dashed lines. Abbreviations: Turb. $=$ turbiditic; Onc. B. $=$ Oncophora Beds. Note that the depth scales differ in Figures 2, 4, 5, 6. 
Streithofen 1, dinoflagellates recovered from two samples at depths of $1142 \mathrm{~m}$ and $1178.9 \mathrm{~m}$ indicate an age older than Eggenburgian, i.e. early Early Miocene, based on the LO of Deflandrea phosphoritica and the co-occurrence of Cordosphaeridium cantharellus. It was not possible to derive a higher biostratigraphic resolution than NN2-NN4 for the intervals of interest, which include the late Egerian, Eggenburgian, Ottnangian-Karpatian and early Badenian. The biostratigraphic tools proved to be too inaccurate for a more precise correlation of upper Ottnangian deposits.

\subsection{Location of the CMI}

According to the presented data, the CMI of PalzerKhomenko et al. (2018) can be identified in the presented sections. A correlation of the CMI for these wells and a comparison to the outdated OMV profile and stratigraphy (Aniwandter et al., 1990) can be seen in Figure 6. The decrease of calcite contents is followed by the decrease of pyrite contents with a delay of 20-100 m. The onset of the CMI is defined by the drop of calcite and the disappearance of calcareous nannofossils (Palzer-Khomenko et al., 2018). Therefore, the CMI starts at $80 \mathrm{~m}$ in the section of Schaubing, between $850 \mathrm{~m}$ and $800 \mathrm{~m}$ in the section of Streithofen 1 and below $1535 \mathrm{~m}$ in the section of Wildendürnbach K4. Note that the resolution in Schaubing is much higher due to the continuous drill core, which allows a more accurate localisation of the CMI onset. At Streithofen 1 and Wildendürnbach K4, the gaps between the drill cores cause uncertainties of c. 50 m. At Schaubing and Streithofen 1, the CMI continues up to the surface, where the Traisen Formation crops out.

At Wildendürnbach K4, the localisation of the upper limit of the CMI remains problematic due to the occurrence of detrital and concretionary calcite-bearing sands. If only samples of the fine-grained background sedimentation (Fig. 5) are taken into account, the recovery of carbonate, calcite and Ca can be localised between $1300 \mathrm{~m}$ and $1250 \mathrm{~m}$. Calcareous nannofossils occur sporadically in one sample at $1254 \mathrm{~m}$ and more continuously from $1054 \mathrm{~m}$ upwards. Pyrite XRD peak heights were not detected for all samples between $1450 \mathrm{~m}$ and $1350 \mathrm{~m}$ and for many (especially for those representing the background sedimentation) samples up to $1150 \mathrm{~m}$. Therefore, the core of the $\mathrm{CMI}$ can be identified between $1500 \mathrm{~m}$ and $1300 \mathrm{~m}$.

Whether the interval between $1250 \mathrm{~m}$ and $1050 \mathrm{~m}$ should be seen as part of the CMI or not constitutes a more challenging question. While $\mathrm{CO}_{3}$, calcite and $\mathrm{Ca}$ steadily increase between $1300 \mathrm{~m}$ and $1250 \mathrm{~m}$, the pyrite contents remain low and calcareous nannofossils remain absent until $1100 \mathrm{~m}$ and $1050 \mathrm{~m}$ (with one exception of marly silts at $1250 \mathrm{~m}$ ). A last snap of low $\mathrm{CO}_{3} \%$ and calcite values occurs at $1100 \mathrm{~m}$. According to the definition of Palzer-Khomenko et al. (2018), the upper boundary of the CMI is marked by the "sustainable increase of pyrite contents and the coeval re-occurrence of calcareous nannofossils". These conditions are best fulfilled for the well interval between $1100 \mathrm{~m}$ and $1050 \mathrm{~m}$. We therefore infer the upper limit of the $\mathrm{CMI}$, and therefore the lithostratigraphic boundary between the Wildendürnbach Formation and the Laa Formation, to lie at c. $1075 \mathrm{~m}$ in this well.

However, the CMI was clearly identified in the interval between $1500 \mathrm{~m}$ and $1300 \mathrm{~m}$, which is significantly below the interval of the former "Oncophora Beds sensu stricto" starting at $1000 \mathrm{~m}$. The turbiditic sands around $1200 \mathrm{~m}$ fall into the upper part of the CMI but clearly overlie the main part of the CMI. Much of the OMV interpretation of the "Oncophora Beds" as open marine sediments is based on the presence of microfossils. Unfortunately, Hamilton (1997) did not describe the exact origin of the samples on which the interpretation of a marine environment is based. Nevertheless, it can be assumed that the analysed microfossils were derived from the micro- and nannofossil-bearing pelitic beds intercalated between the massive sands between $1000 \mathrm{~m}$ and $800 \mathrm{~m}$ rather than from the fossil-free interval below. Sedimentary structures typical for turbidites, which were also taken as arguments for marine conditions, are indicators of considerable water depth and sedimentation processes but have no significance concerning the reconstruction of water salinity.

\subsection{A revised correlation of Traisen Formation and "Oncophora Beds" sensu OMV}

Palzer-Khomenko et al. (2018) inferred a basin-wide synchronous event during the late Ottnangian causing a carbonate crisis and the $\mathrm{CMI}$, which may correspond to the environmental change during the time interval of the brackish Rzehakia Lake System proposed by Harzhauser and Mandic (2008). Consequently, the sediments analysed by Hamilton (1997) attributed to a fully marine facies do not correlate chronologically to the Traisen Formation and to the Rzehakia Lake System comprised by the CMI (Fig. 6). Thus, the so-called "Oncophora Beds" sensu OMV around Wildendürnbach, especially the typical massive sands between $1000 \mathrm{~m}$ and $800 \mathrm{~m}$ at Wildendürnbach K4, overlie the $\mathrm{CMI}$ and are inevitably younger. Following the definition of Piller et al. (2007, p. 155), who described the Ottnangian in the Central Paratethys as a "strictly twofold stage with a normal marine development in its lower part and a predominance of restricted marine to fresh water environments in its upper part", we interpret the CMI as an excellent basin-wide proxy for the late Ottnangian.

Aniwandter et al. (1990) have previously described the contradicting interpretations for the so-called "Oncophora Beds" at the Czech border. While Austrian workers attributed them to the Ottnangian by correlation with the Traisen Formation further to the south, geologists from the Czech Republic assumed a Karpatian age based on the presence of the Ostracoda Senesia aff. vadaszi (Aniwandter et al., 1990).

According to these findings, we attribute the former sand-rich "Oncophora Beds" sensu OMV in the area of Wildendürnbach to the Karpatian and thus these form part of the Karpatian Laa Formation (Roegl et al., 1997). The underlying pelitic CMI sediments at Wildendürnbach K4 comprise the Wildendürnbach Formation (sensu Palzer-Khomenko et al., 2018). 


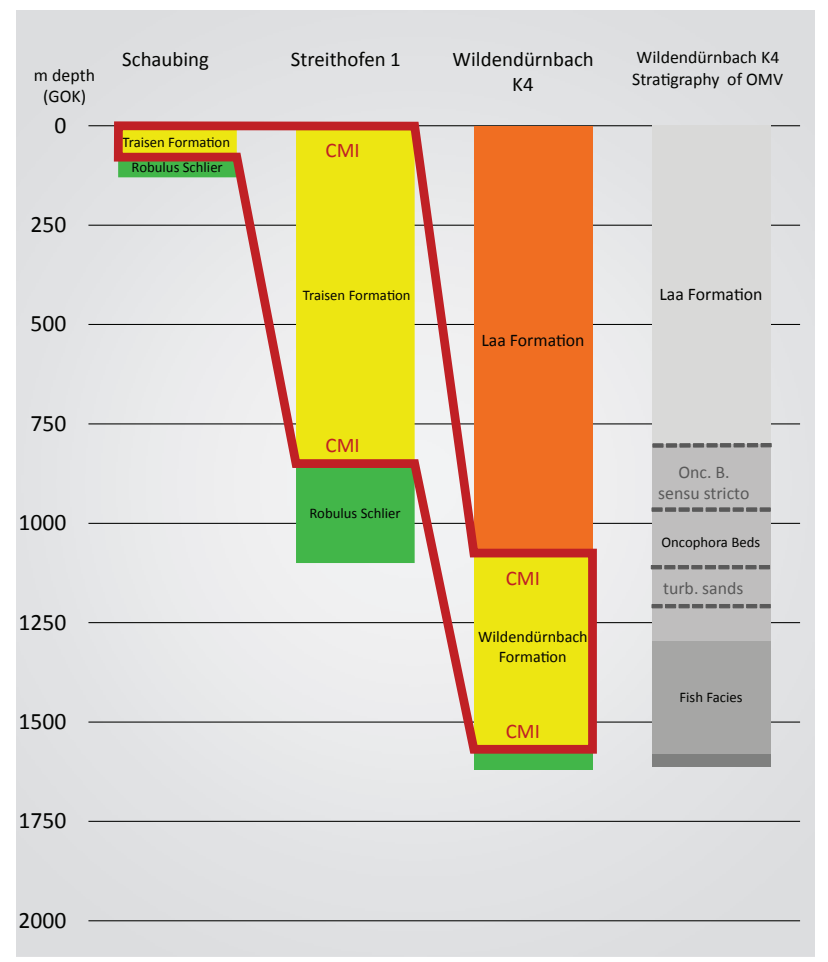

Figure 6. Correlation of the Calcite Minimum Interval (CMI) for the wells of Schaubing, Streithofen 1 and Wildendürnbach K4. The OMV internal short profile is shown in grey scales for comparison. The upper Ottnangian Wildendürnbach Formation is underlying the "Oncophora Beds" sensu OMV. Please note that the typical massive sands of the "Oncophora Beds" sensu OMV start in Wildendürnbach K4 at $1000 \mathrm{~m}$. The pelites interrupted by sand packages (turbiditic sands) between $1200 \mathrm{~m}$ and $1000 \mathrm{~m}$ were attributed to the Oncophora Beds in some, but not in all, OMV internal descriptions. Please note that the depth scales differ in Figures 2, 4, 5, 6.
The stratigraphic concepts of Piller et al. (2004), OMV reports and descriptions of Palzer-Khomenko et al. (2018) are compared in Figure 7. The yellow box marks the position of the CMI and the Rzehakia Lake System of Harzhauser and Mandic (2008) around the Burdigalian Bur4 sea-level lowstand (Piller et al., 2007). Palzer-Khomenko et al. (2018) propose to define the upper and lower limits of the Traisen Formation and the Wildendürnbach Formation, the upper limit of the Zellerndorf Formation and the Robulus Schlier as well as the lower limit of the Laa Formation by the CMI signal.

\subsection{Palaeogeography}

Sikula and Nehyba (2004) analysed the numerous drill logs and seismic reflection profiles north of Wildendürnbach and recognised 13 well log facies. The resulting thickness maps indicate a major Karpatian input centre directly north of the Austrian border at the Carpathian fold and thrust front. Comparisons to well logs from Wildendürnbach K4 indicate strong similarities to the interval of the "Oncophora Beds". We therefore correlate the "Oncophora Beds" sensu OMV around Wildendürnbach K4 to the large Karpatian clastic input centre described by Sikula and Nehyba (2004).

Therefore, we assume different provenance areas and sediment input centres for the Traisen Formation in the south and for the former "Oncophora Beds" in the north (Fig. 8). The sediments of the Traisen Formation were delivered by a late Ottnangian river system probably from the Alpine Orogen into the Rzehakia Lake System. Heavy mineral data of Knierzinger (2015) indicate mainly a delivery of material from the Austroalpine Crystalline Complex south of the Rhenodanubian Flysch Zone and the Northern Calcareous Alps (NCA). Therefore, an Enns-type river system overflowing or cutting through the NCA was necessary to deliver the clastic deposits of the Traisen Formation. Following Dunkl et al. (2005) and Frisch et al. (1998), this river system was caught at some point by the NNE-SSW-oriented fault systems related to lateral extrusion and deflected to the east probably to the Vienna Basin following prominent fault systems like the Mur-Mürz fault (Salcher et al., 2012). Kováč et al. (2004) described coeval depocentres at the SW margin of the early Vienna Basin. Since that time, the uprising NCA acted mainly as a watershed south of the LAMB. Sands of the "Oncophora Beds" sensu OMV of Wildendürnbach K4 were delivered by Karpatian-aged pro-delta turbiditic flows from the Carpathian fold and thrust front represented by the initial Waschberg Zone in the east into a

Figure 7. Comparison of stratigraphic concepts for the lower Miocene Ottnangian and early Karpatian Lower Austrian Molasse Basin (LAMB) of Piller et al. (2004), of OMV internal reports, of Hamilton (1997) and of Palzer-Khomenko et al. (2018). The Ottnangian/Karpatian boundary correlates to the transgression following the Bur4 lowstand (Hardenbol et al., 1998) and the termination of the Rzehakia Lake System (Harzhauser and Mandic, 2008). Palzer-Khomenko et al. (2018) defined stratigraphic units using the CMI signal. While early, middle and late Ottnangian boundaries are distinguished in Bavaria (Heckeberg et al., 2010; Pippèrr and Reichenbacher, 2017), a corresponding definition and differentiation are unknown in Lower Austria. Abbreviations: For. Facies = foraminiferal facies; Robulus Schlier s. I. = Robulus Schlier sensu latu; Fm. = Formation. Chronostratigraphy based on Time Scale Creator Version 7.1 (https://engineering.purdue.edu/ Stratigraphy/tscreator) using Gradstein et al. (2012). 
marine LAMB. A delivery from the eastern approximating Waschberg Zone was previously stated by Hamilton (1997). According to the work of Sikula and Nehyba (2004), the activity of the Karpatian sedimentary system and depocentre was lower at the beginning of the Karpatian (Fig. 8C) and increased with time due to the approaching Waschberg thrust units (Fig. 8D).

\section{Conclusions}

The identification of the CMI as a lithological and chemical marker of the Rzehakia Lake System, which represents a chronostratigraphic basin-wide upper Ottnangian key horizon (Palzer-Khomenko et al., 2018) in the well sections of Schaubing, Streithofen 1 and Wildendürnbach $\mathrm{K} 4$, allows a more precise correlation between these wells and a new stratigraphic concept in the LAMB. While the Traisen Formation (Gebhardt et al., 2013) in the south is clearly a part of the CMI, the former "Oncophora
Beds" in the well of Wildendürnbach K4 (Hamilton, 1997) are overlying this interval. Therefore, these "Oncophora Beds" do not represent upper Ottnangian but rather Karpatian deposits. A comparison with data from Sikula and Nehyba (2004) indicates that these sands were delivered from an eastern Karpatian-aged input centre at the Carpathian fold and thrust front. Therefore, we assume two spatially and temporally independent input centres: (1) an older, late Ottnangian input centre to the south delivering the sands of the Traisen Formation into the brackish Rzehakia Lake System during the Bur4 sea-level lowstand at around 17.3 Ma (according to Krijgsman and Piller, 2012), and (2) a younger, Karpatian input centre in the north delivering the sands of the former "Oncophora/Rzehakia Beds" sensu OMV around Wildendürnbach into a fully marine environment after the major Karpatian transgression, i.e. the sea-level rise at the beginning of the highstand Bur4 of the Burdigalian,

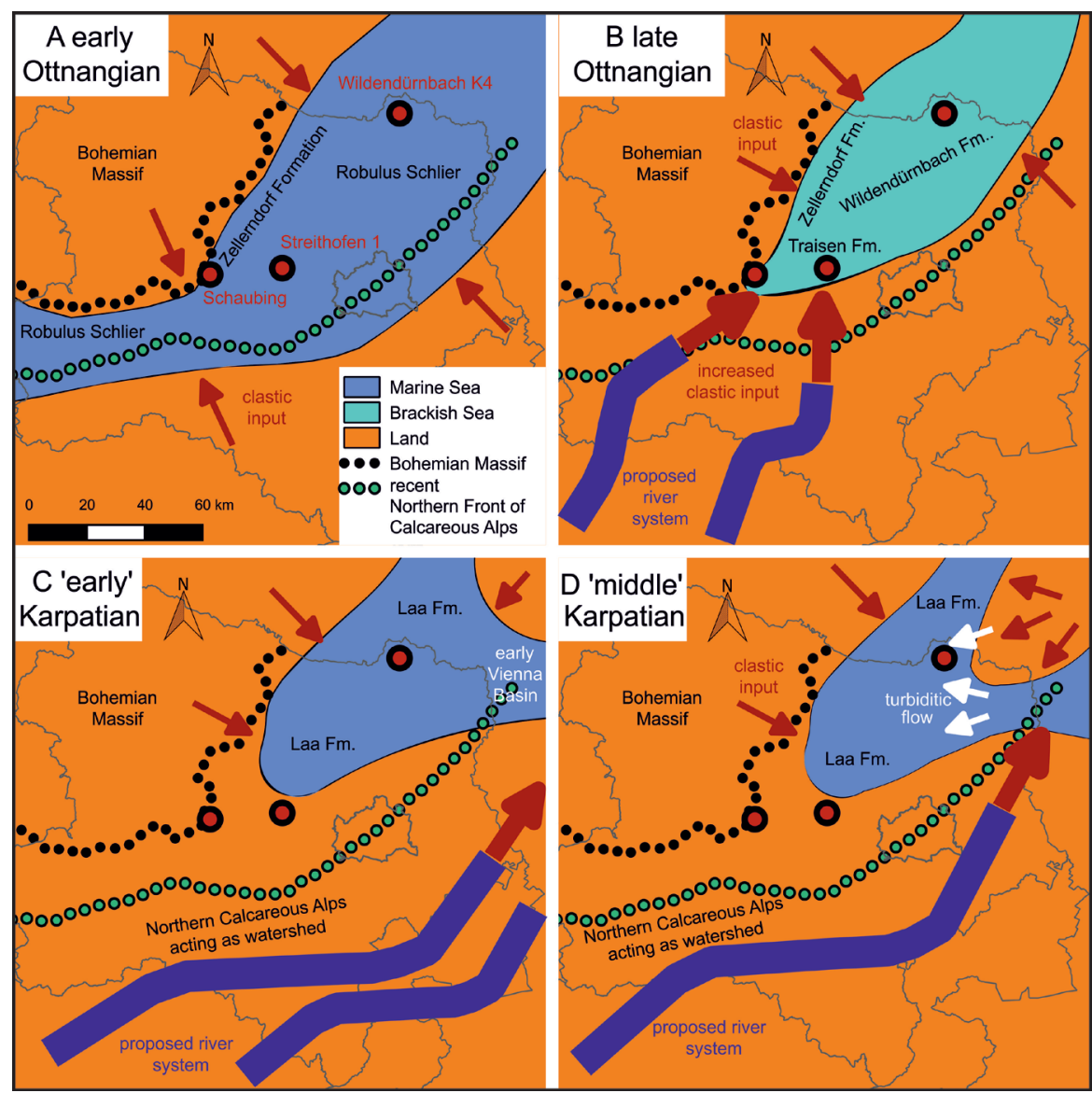

Figure 8. Palaeogeographic evolution of the Lower Austrian Molasse Basin (LAMB) based on reconstructions for the Early Miocene, Ottnangian and early Karpatian boundaries considering reconstructions by Beidinger and Decker (2014), Bieg (2005), Sikula and Nehyba (2004), Frisch et al. (1998), Dunkl et al. (2005) and Kováč et al. (2004). Limits of exposed Bohemian Massif rocks and the recent northern front of the NCA are based on Beidinger and Decker (2014). A. The connection to the western part of the Central Paratethys (west of Amstetten) was a large open seaway during the early Ottnangian (Grunert et al., 2010b). B. This Molasse seaway is closed by tectonic processes driven by northwards moving Alpine thrust systems and the eustatic Bur4 regression during the late Ottnangian. Isolation of the LAMB triggers an environmental crisis, creates the Rzehakia Lake System (Harzhauser and Mandic, 2008) and causes the CMI during the sea-level lowstand (Palzer-Khomenko et al., 2018). In the south, a large clastic input centre develops. C. The "early" Karpatian transgression and the beginning subsidence of the Vienna Basin re-established connections to the east. D. This transgression was followed by the development of a "middle" Karpatian clastic input centre delivering material from the east at the Austrian/Czech border (Sant et al., 2017). younger than 17.2 Ma (Roetzel et al., 2014). However, the timing of the Ottnangian/Karpatian boundary is still under debate, and a considerably younger age of 16.8 Ma was considered by Reichenbacher et al. (2013)

Thus, the problem of the contradicting interpretations concerning depositional environments (shallow-brackish versus deep-water fully marine, Hamilton, 1997; Mandic and Ćorić, 2007; Gebhardt et al., 2013) can be solved as both interpretations apply correctly and as the "Oncophora Beds" in the wells around Wildendürnbach are in fact Karpatian in age. As there is no Rzehakia described for these sands, we recommend to avoid the term "Oncophora Beds" and attribute these sediments to be a part of the Laa Formation.

\section{Acknowledgements}

We would like to thank the OMV for funding the Project in the course of a University of Vienna-OMV cooperation project (grant number FA536022) and for providing the investigated drill cores and archive data, as well as the Geological Survey of Austria for providing the drill core of Schaubing. Special thanks go to Gebhardt Holger for his support. Further on, we thank Stjepan Coric, Reinhard Roetzel, Mathias Harzhauser, Dörte Theobalt, Philipp Strauß and Thomas Kuffner for fruitful discussions and for their support. 


\section{References}

Aniwandter, A., Bimka, J. and Zych, D., 1990. Facies development of miocene formations in the southwestern part of the Carpathian foredeep and its oil and gas prospects. Petroleum Geology and Geochemistry, Mineral Deposits, 186-203.

Beidinger, A. and Decker, K., 2014. Quantifying Early Miocene in-sequence and out-of-sequence thrusting at the Alpine-Carpathian junction. Tectonics, 33/3, 222-252. https://doi.org/10.1002/2012tc003250.

Benedek, P.N., 1972. Phytoplanktonten aus dem Mittelund Oberoligozän von Tönisberg (Niederrheingebiet). Palaeontographica, Abteilung B, 137, 1-71.

Benedek, P.N., Gocht, H. and Sarjeant, W.A.S., 1982. The dinoflagellate cyst genus Pentadinium Gerlach: a re-examination. Neues Jahrbuch für Geologie und Pälaontologie, Abhandlungen, 162/3, 265-285.

Bieg, U., 2005. Palaeooceanographic modeling in global and regional scale: An example from the Burdigalian Seaway Upper Marine Molasse (Early Miocene). Doctoral Thesis, Eberhard-Karls-Universität Tübingen, 118 pp.

Bujak, J.P., Downie, C., Eaton, G.L. and Williams, G.L., 1980. Dinoflagellate cysts and acritarchs from the Eocene of southern England. Special Papers in Palaeontology, 24, 100.

Burnett, J.A., 1998. Upper Cretaceous. Chapman \& Hall, Cambridge, Calcareous Nannofossil Biostratigraphy, 132-199.

Ćorić, S. and Roegl, F., 2004. Roggendorf-1 Borehole, A Key-Section for Lower Badenian transgressions and the stratigraphic position of the Grund Fromation (Molasse Basin, Lower Austria). Geologica Carpathica, 55/2, 165-178.

Ćorić, S., Roetzel, R., Krenmayr, H.-G. and Gebhardt, H., 2013. Excursion E2 - Fazies und Stratigrafie der oligozänen und miozänen Sedimente in der alpinen Vortiefe auf den Blättern 55-Ober-Grafendorf und 56 St. Pölten. In: Gebhardt, H., (ed). Arbeitstagung 2013 - Geologie der Kartenblätter 55 Ober-Grafendorf und 56 St. Pölten. Melk, 236-269.

Čtyroký, P., 1972. Die Molluskenfauna der Rzehakia(Oncophora)-Schichten Mährens. Annalen des Naturhistorischen Museums in Wien, 76, 41-141.

Dunkl, I., Kuhlemann, J., Reinecker, J. and Frisch, W., 2005. Cenozoic relief evolution of the Eastern Alps constraints from apatite fission track age-provenance of Neogene intramontane sediments. Austrian Journal of Earth Sciences, 98, 92-105.

Eaton, G.L., 1976. Dinoflagellate cysts from the Bracklesham Beds (Eocene) of the Isle of Wight, southern England. British Museum (Natural History) Geology, Bulletin, 26, 227-332.

Egger, H., Coric, S., Ahl, A., Berka, R., Heinrich, M., Hofmann, C.-C., Lenhardt, W., Linner, M., Moshammer, B., Pavuza, R., Roegl, F., Sachsenhofer, R.F., Schedl, A., Schnabel, W., Slapansky, P., Wagreich, M., Wessely, G. and Wimmer-Frey, I., 2017. Erläuterungen zu Blatt 56 St. Pölten. Verlag der Geologischen Bundesanstalt (GBA), Vienna, Geologische Karte der Republik Österreich 1:50.000: Erläuterung, 167 pp.
Frisch, W., Kuhlemann, J., Dunkl, I. and Brügel, A., 1998. Palinspastic reconstruction and topographic evolution of the Eastern Alps during late Tertiary tectonic extrusion. Tectonophysics, 297/1-4, 1-15. https://doi.org/10.1016/ S0040-1951(98)00160-7.

Gebhardt, H., Ćorić, S., Krenmayr, H.-G., Steininger, H. and Schweigl, J., 2013. Neudefinition von lithostratigraphischen Einheiten des oberen Ottnangium (Unter-Miozän) in der alpin-karpatischen Vortiefe Niederösterreichs: Pixendorf-Gruppe, Traisen-Formation und Dietersdorf-Formation. Jahrbuch der Geologischen Bundesanstalt, 153, 15-32.

Gerlach, E., 1961. Mikrofossilien aus dem Oligozän und Miozän Nordwestdeutschlands, unter besonderer Berücksichtigung der Hystrichosphaeren und Dinoflagellaten. Neues Jahrbuch für Geologie und Paläontologie, Abhandlungen, 112/2, 143-228.

Gradstein, F.M., Ogg, J.G., Schmitz, M.D. and Ogg, G.M., 2012. The Geologic Time Scale 2012. Elsevier B V. https:// doi.org/10.1016/C2011-1-08249-8.

Grunert, P., Soliman, A., Ćorić, S., Scholger, R., Harzhauser, M. and Piller, W.E., 2010a. Stratigraphic re-evaluation of the stratotype for the regional Ottnangian stage (Central Paratethys, middle Burdigalian). Newsletters on Stratigraphy, 44/1, 1-16. https://doi. org/10.1127/0078-0421/2010/0001.

Grunert, P., Soliman, A., Harzhauser, M., Müllegger, S., Piller, W.E., Roetzel, R. and Roegl, F., 2010b. Upwelling conditions in the Early Miocene Central Paratethys Sea. Geologica Carpathica, 61/2, 129-145. https://doi. org/10.2478/v10096-010-0006-3.

Grunert, P., Soliman, A., Ćorić, S., Roetzel, R., Harzhauser, M. and Piller, W.E., 2012. Facies development along the tide-influenced shelf of the Burdigalian Seaway: An example from the Ottnangian stratotype (Early Miocene, middle Burdigalian). Marine Micropaleontology, 84-85, 14-36. https://doi.org/10.1016/j. marmicro.2011.11.004.

Grunert, P., Hinsch, R., Sachsenhofer, R.F., Bechtel, A., Ćorić, S., Harzhauser, M., Piller, W.E. and Sperl, H., 2013. Early Burdigalian infill of the Puchkirchen Trough (North Alpine Foreland Basin, Central Paratethys): Facies development and sequence stratigraphy. Marine and Petroleum Geology, 39/1, 164-186. https://doi.org/10.1016/j. marpetgeo.2012.08.009.

Habib, D., 1972. Dinoflagellate stratigraphy Leg 11, Deep Sea Drilling Project. Deep Sea Drilling Project, Washington, Initial Reports, 11, 367-425.

Hamilton, W., 1997. Die Oncophoraschichten im Bereich Altprerau/Wildendürnbach und ihre Entstehung. In: Hofmann, T., (ed.), Das Land um Laa an der Thaya. Volume 17, Österreichische Geologische Gesellschaft, Vienna, pp. 97-98.

Hardenbol, J., Thierry, J., Farley, M.B., Jacquin, T., Graciansky, P.-C. and Vail, P.R., 1998. Mesozoic and Cenozoic Sequence Chronostratigraphic Framework of European Basins. In: Graciansky, C.-P., Hardenbol, J., Jacquim, T., and Vail, P. R., (eds.), Mesozoic and Cenozoic sequence 
stratigraphy of European basins. Society of Sedimentary Geology, Tulsa, pp. 3-13.

Harland, R. and Hill, J., 1979. A reappraisal of the Cainozoic dinoflagellate cyst "Hystrichosphaeridium" choanophorum Deflandre et Cookson 1955. Review of Palaeobotany and Palynology, 28, 37-45.

Harzhauser, M. and Mandic, O., 2008. Neogene lake systems of Central and South-Eastern Europe: Faunal diversity, gradients and interrelations. Palaeogeography, Palaeoclimatology, Palaeoecology, 260/3-4, 417-434. https://doi.org/10.1016/j.palaeo.2007.12.013.

Head, M.J., Norris, G. and Mudie, P.J., 1989. Palynology and dinocyst stratigraphy of the miocene in ODP Leg 105, Hole 645E, Baffin Bay. Proceedings of the Ocean Drilling Program, 105, 467-514.

Heckeberg, N., Pippèrr, M., Läuchli, B., Heimann, F.U.M. and Reichenbacher, B., 2010. The Upper Marine Molasse (Burdigalian, Ottnangian) in Southwest Germany - facies interpretation and a new lithostratigraphic terminology. Zeitschrift der Deutschen Gesellschaft für Geowissenschaften, 161/3, 285-302. https://doi. org/10.1127/1860-1804/2010/0161-0285.

Jiménez-Moreno, G., Head, M.J. and Harzhauser, M., 2006. Early and Middle Miocene dinoflagellate cyst stratigraphy of the central Paratethys, central Europe. Journal of Micropalaeontology, 25, 113-139.

Kapounek, J., Kröll, A., Papp, A. and Turnovsky, K., 1965. Die Verbreitung von Oligozän, Unter- und Mittelmiozän in Niederösterreich. Erdöl-Erdgas Zeitschrift, 81, 109-115.

Knierzinger, W., 2015. Provenance Analysis of lower Miocene Sediments in the Lower Austrian Molasse Basin. M.Sc. Thesis, University of Vienna.

Knierzinger, W., Wagreich, M., Palzer-Khomenko, M., Gier, S., Meszar, M., Lee, E.Y., Koukal, V., Strauss, P., 2018. Provenance and palaeogeographic evolution of Lower Miocene sediments in the eastern North Alpine Foreland Basin. Swiss Journal of Geosciences. https://doi. org/10.1007/s00015-018-0312-9

Kováč, M., Baráth, I., Harzhauser, M., Hlavatý, I. and Hudáčková, N., 2004. Miocene depositional systems and sequence stratigraphy of the Vienna Basin. CFS Courier Forschungsinstitut Senckenberg, 246, 187-212.

Kováč, M., Hudáčková, N., Halásová, E., Kováčová, M., Holcová, K., Oszczypko-Clowes, M., Báldi, K., Less, G., Nagymarosy, A., Ruman, A., Klučiar, T. and Jamrich, M., 2017. The Central Paratethys palaeoceanography: a water circulation model based on microfossil proxies, climate, and changes of depositional environment. Acta Geologica Slovaca, 9/2, 75-114.

Kowalke, T. and Reichenbacher, B., 2005. Early Miocene (Ottnangian) Mollusca of the Western Paratethysontogenetic strategies and palaeo-environments. Geobios, 38/5, 609-635. https://doi.org/10.1016/j. geobios.2004.03.006.

Krenmayr, H.-G. and Roetzel, R., 2000. Die lithostratigraphische Formalisierung der Melker- und Linzer Sande: Die «Linz-Melk-Formation». Berichte des Institutes für
Erdwissenschaften der Karl-Franzens-Universität Graz/ Austria, 2, 10.

Krenmayr, H.-G., Mandl, G.W., Nowotny, A., Roetzel, R. and Scharbert, S., 2002. Geologische Karte von Niederösterreich 1:200.000: Legende und kurze Erläuterung, Wien, $47 \mathrm{pp}$.

Krijgsman, W. and Piller, W.E., 2012. Regional Stages; Central and Eastern Paratethys. In: Gradstein, F. M., Ogg, J. G., Schmitz, M. D. and Ogg, G. M., (eds.), The Geologic Time Scale 2012. Elsevier, Oxford, United Kingdom, pp. 935-937.

Kuffner, T., 2001. Depositional Environment and Reservois Properties of selected Egerian, Eggenburgian and Ottnangian cores from the Wascherg Zone. OMV - Laboratory for Exploration and Production.

Liebl, D., Gegg, L., Schützinger, S., Lechner, T., Löhrl, E., Penk, S.B.R., Gierl, C., Pippèrr, M. and Reichenbacher, B., 2013. Marine, brackish or freshwater? The paleoecology of the northern Molasse Basin in the late Early Miocene, Palaeobiology \& Geobiology of Fossil Lagerstätten through Earth History. Volume Abstracts, Göttingen, 105-106.

Mandic, O. and Ćorić, S., 2007. Eine neue Molluskenfauna aus dem oberen Ottnangium von Rassing (NÖ) - taxonomische, biostratigrafische, paläoökologische und paläobiogeografische Auswertung. Jahrbuch der Geologischen Bundesanstalt, 147/1-2, 387-397.

Martini, E., Year. Published Standard Tertiary and Quaternary Calcareous Nannoplankton Zonation. In: Proceedings II Planktonic Conference, Rom, 1971, Edizione Tecnoscienza, 738-785.

Mueller, G. and Gastner, M., 1971.The "Karbonat-Bombe",a simple device for the determination of the carbonate content in sediments, soils, and other materials. Neues Jahrbuch für Mineralogie. Monatshefte, 10, 466-469.

Nehyba, S. and Sikula, J., 2007. Depositional architecture, sequence stratigraphy and geodynamic development of the Carpathian Foredeep (Czech Republic). Geologica Carpathica, 58/1, 53-69.

Palzer-Khomenko, M., Wagreich, M., Knierzinger, W., Meszar, M.-E., Gier, S., Kallanxhi, M.-E. and Soliman, A., 2018. A calcite crisis unravelling Early Miocene (Ottnangian) stratigraphy in the North Alpine-Carpathian Foreland Basin: A litho- and chemostratigraphic marker for the Rzehakia Lake System. Geologica Carpathica. https://doi.org/10.1515/GEOCA-2018-0019.

Peña, F.-A.-C., 2007. The Early Miocene Upper Marine Molasse of the German part of the Molasse Basin - a subsurface study. Sequence Stratigraphy, Depositional Environment and Architecture, 3D Basin Modeling. DoctoralThesis, Eberhard-Karls-Universität.

Piller, W.E., Egger, H., Erhart, C.W., Gross, M., Harzhauser, M., Hubmann, B., van Husen, D., Krenmayr, H.-G., Krystyn, L., Lein, R., Lukeneder, A., Mandl, G.W., Roegl, F., Roetzel, R., Rupp, R., Schnabel, W., Schönlaub, H.P., Summersberger, H., Wagreich, M. and Wessely, G., 2004. Die stratigrafische Tabelle von Österreich 2004 (sedimentäre Schichtfolgen). Kommission für die paläontologische 
und stratigrafische Erforschung der Österreichischen Akademien der Wissenschaften und Österreichische Stratigraphische Kommission, Vienna.

Piller, W.E., Harzhauser, M. and Mandic, O., 2007. Miocene Central Paratethys stratigraphy - Current status and future directions. Stratigraphy, 4/2-3, 151-168.

Pippèrr, M. and Reichenbacher, B., 2010. Foraminifera from the borehole Altdorf (SE Germany): Proxies for Ottnangian (early Miocene) palaeoenvironments of the Central Paratethys. Palaeogeography, Palaeoclimatology, Palaeoecology, 289/1-4, 62-80. https://doi. org/10.1016/j.palaeo.2010.02.009.

Pippèrr, M. and Reichenbacher, B., 2017. Late Early Miocene palaeoenvironmental changes in the North Alpine Foreland Basin. Palaeogeography, Palaeoclimatology, Palaeoecology, 468, 485-502. https://doi.org/10.1016/j. palaeo.2017.01.002.

Pippèrr, M., Reichenbacher, B., Kirscher, U., Sant, K. and Hanebeck, H., 2018. The middle Burdigalian in the North Alpine Foreland Basin (Bavaria, SE Germany) - a lithostratigraphic, biostratigraphic and magnetostratigraphic re-evaluation. Newsletters on Stratigraphy. https:// doi.org/10.1127/nos/2017/0403.

Reichenbacher, B., Wout, K., Yannick, L., Pippèrr, M., Van Baak, C.G.C., Chang, L., Kälin, D., Jost, J., Doppler, G., Jung, D., Prieto, J., Abdul Aziz, H., Böhme, M., Garnish, J., Kirscher, U. and Bachtadse, V., 2013. A new magnetostratigraphic framework for the lower Miocene (Burdigalian/Ottnangian, Karpatian) in the North Alpine Foreland Basin. Swiss Journal of Geosciences, 106, 309-334. https://doi.org/10.1007/s00015013-0142-8.

Robinson, D. and Zimmer, W., 1989. Seismic stratigraphy of Late Oligocene Puchkirchen Formation of upper Austria. Geologische Rundschau, 78/1, 49-79.

Roegl, F. and Steininger, F.F., 1983. Vom Zerfall der Tethys zu Mediterran und Paratethys: Die neogene Paläogeographie und Palinspastik des zirkum-mediterranen Raumes. Annalen des Naturhistorischen Museums in Wien: Serie A, 85, 135-163.

Roegl, F., Krhovský, J. and Hamrsmid, B., 1997. Die Typuslokalität der Laaer Schichten. In: Hofmann, T., (ed.), Das Land um Laa an der Thaya. Volume 17, Österreichische Geologische Gesellschaft, Vienna, pp. 75-82.

Roetzel, R. and Kurzweil, H., 1986. Die Schwerminerale in niederösterreichischen Quarzsanden und ihre wirtschaftliche Bedeutung. Archiv für Lagerstättenforschung der Geologischen Bundesanstalt, 7, 199-216.

Roetzel, R., Mandic, O. and Steininger, F.F., 1999. Lithostratigraphie und Chronostratigraphie der tertiaeren Sedimente im westlichen Weinviertel und angrenzenden Waldviertel. In: Roetzel, R., (ed). Arbeitstagung 1999: Retz-Hollabrunn. Geologische Bundesanstalt, Vienna, Austria, 38-54.

Roetzel, R., Coric, S., Galovic, I. and Rögl, F., 2006. Early Miocene (Ottnangian) coastal upwelling conditions along the southeastern scarp of the Bohemian Massif
(Parisdorf, Lower Austria, Central Paratethys). Beiträge zur Paläontologie, 30, 387-413.

Roetzel, R., Wimmer-Frey, I., de Leeuw, A., Mandic, O., Márton, E., Nehyba, S., Kuiper, K.F. and Scholger, R., 2014. Lower Miocene (upper Burdigalian, Karpatian) volcanic ashfall at the south- eastern margin of the Bohemian Massif in Austria - new evidence from 40Ar/39Ar- dating, palaeomagnetic, geochemical and mineralogical investigations. Austrian Journal of Earth Sciences, 107/2, 2-22. Rupp, C., Hofmann, T., Jochum, B., Pfleiderer, S., Schedl, A., Schindlbauer, G., Schubert, G., Slapansky, P., Tilch, N., Van Husen, D., Wagner, L.R. and Wimmer-Frey, I., 2008. Erläuterungen zu Blatt 47 Ried im Innkreis. Verlag der Geologischen Bundesanstalt (GBA), Wien, 100 pp.

Rzehak, A., 1882. Oncophora, ein neues Bivalvengenus aus dem mährischen Tertiär. 41-42.

Salcher, B.C., Meurers, B., Smit, J., Decker, K., Hölzel, M. and Wagreich, M., 2012. Strike-slip tectonics and Quaternary basin formation along the Vienna Basin fault system inferred from Bouguer gravity derivatives. Tectonics, 31/3. https://doi.org/10.1029/2011tc002979.

Sant, K., V. Palcu, D., Mandic, O. and Krijgsman, W., 2017. Changing seas in the Early-Middle Miocene of Central Europe: a Mediterranean approach to Paratethyan stratigraphy. Terra Nova, 29/5, 273-281. https://doi. org/10.1111/ter.12273.

Sauer, R. and Kuffner, T., 1997. Sedimentological and Petrological Analyses of selected Wildendürnbach cores. OMV, 1-45. [unpublished report]

Schuster, R., Daurer, R., Krenmayr, H.-G., Linner, M., Mandl, G.W., Pestal, G. and Reitner, J., 2015. Rocky Austria. Geologie von Österreich - kurz und bunt. Geological Survey of Austria, Vienna.

Sikula, J. and Nehyba, S., 2004. Lithofacies analysis of Miocene sediments in the southern part of Carpathian Foredeep, based on the re-interpretation of drill logging data. Bulletin of Geosciences, 79/3, 167-176.

Soliman, A., 2012. Oligocene dinoflagellate cysts from the North Alpine Foreland Basin: new data from the Eggerding Formation (Austria). Geologica Carpathica, 63, 49-70.

Soliman, A., Coric, S., Head, M.J., Piller, W.E. and Beialy, S.Y.E., 2012. Lower and Middle Miocene biostratigraphy, Gulf of Suez, Egypt based on dinoflagellate cysts and calcareous nannofossils. Palynology, 36/1, 38-79.

Steininger, F.F., Frasl, G., Vetters, W. and Höck, V., 1983. Zur Geologie des Kristallins und Tertiärs der weiteren Umgebung von Eggenburg. Österreichische Geologische Gesellschaft, Eggenburg, Exkursion der Österreichischen Geologischen Gesellschaft.

Strauss, C., Lund, J.J. and Lund-Christensen, J., 2001. Miocene dinoflagellate cyst biostratigraphy of the Nieder Ochtenhausen research borehole (NW Germany). Geologisches Jahrbuch, Serie A, 152, 395-447.

Wagner, L.R., 1998. Tectono-stratigraphy and Hydrocarbons in the Molasse Foredeep of Salzburg, Upper and Lower Austria. Geological Society London Special Publications 134/1, 339-369 
Wall, D., 1967. Fossil microplancton in deep-sea cores from the Caribbean Sea. Palaeontology, 10/1, 95-123.

Wessely, G., 2006. Niederösterreich. Geologische Bundesanstalt, Vienna.

Wimmer-Frey, I., Corić, S., Peresson, M. and Rabeder, J., 2013. Mineralogische und korngrößenmäßige
Untersuchungen an quartären und miozänen Sedimenten auf den Kartenblättern 55 Ober-Grafendorf und 56 St. Pölten. In: Gebhardt, H., (ed). Arbeitstagung 2013 - Geologie der Kartenblätter 55 Ober-Grafendorf und 56 St. Pölten. Volume 13, Geologische Bundesanstalt, Melk, 138-140.

Submitted: 05022018

Accepted: 17052018

Markus PALZER-KHOMENKO'), Michael WAGREICH ${ }^{1)}$, Mădălina-Elena KALLANXHI'), Ali SOLIMAN ${ }^{3)}$, Wolfgang KNIERZINGER ${ }^{1)}$, Maria MESZAR ${ }^{1)}$ \& Susanne GIER ${ }^{1)}$

1) Department of Geodynamics and Sedimentology, University of Vienna, Althanstraße 14, 1090 Wien, Austria;

2) Department of Geology. Faculty of Biology and Geology, Babeş-Bolyai University, Str. Mihail Kogălniceanu 1, Cluj-Napoca 400084, Romania; 3) Geology Department, Faculty of Science, Tanta University, Tanta 31527, Egypt;

*) Corresponding author: markus.palzer@gmx.at 